\title{
SIMULATION OF WATER-TABLE RESPONSE TO \\ MANAGEMENT ALTERNATIVES, CENTRAL PART OF THE WESTERN SAN JOAQUIN VALLEY, CALIFORNIA
}

By Kenneth Belitz and Steven P. Phillips

U.S. GEOLOGICAL SURVEY

Water-Resources Investigations Report 91-4193

THIS REPORT REPLACES ONE PREVIOUSLY ISSUED UNDER THIS NUMBER. THE PREVIOUS REPORT IS IN ERROR AND SHOULD NOT BE USED.

Prepared in cooperation with the

U.S. BUREAU OF RECLAMATION

$\frac{8}{8}$ 


\title{
U.S. DEPARTMENT OF THE INTERIOR BRUCE BABBITT, Secretary
}

\author{
U.S. GEOLOGICAL SURVEY \\ Gordon P. Eaton, Director
}

Any use of trade, product, or firm names in this publication is for descriptive purposes only and does not imply endorsement by the U.S. Government.

For sale by the U.S. Geological Survey

Earth Science Information Center

Open-File Reports Section

Box 25286, MS 517

Denver Federal Center

Denver, CO 80225

For additional information write to:

District Chief

U.S. Geological Survey

Federal Building, Room W-2233

2800 Cottage Way

Sacramento, CA 95825 


\title{
CONTENTS
}

\author{
Abstract 1 \\ Introduction 1 \\ Hydrogeologic setting $\mathbf{3}$ \\ Numerical model $\mathbf{3}$ \\ Simulation of water-table response to management alternatives 9 \\ Maintenance of present practices 10 \\ Land retirement 11 \\ Improvement in irrigation efficiency 13 \\ Reduce recharge to 0.46 foot per year 13 \\ Reduce recharge by specified percentage 18 \\ Ground-water pumping 18 \\ Constant pumping rate 18 \\ Variable pumping rate 23 \\ Increased pumping from the confined zone only 25 \\ Reduce recharge and increase ground-water pumping 28 \\ Management alternatives for the San Luis Unit proposed by the U.S. Bureau of Reclamation 32 \\ Discussion of management alternatives 35 \\ Summary and conclusions $\mathbf{3 8}$ \\ References cited \\ 39
}

\section{FIGURES}

1. Map showing model grid and lateral boundary conditions 2

2. Generalized hydrogeologic section of the semiconfined zone perpendicular to the axis of the

San Joaquin Valley 4

3-6. Maps showing:

3. Water-budget subarea boundaries 6

4. Subareas used for evaluating vertical distribution of ground-water pumpage 6

5. Measured and simulated depth to water, October $1984 \quad 7$

6. Areal distribution of year round and seasonal measured and simulated number of model cells subject to bare-soil evaporation, 19848

7,8. Graphs showing:

7. Measured and simulated number of model cells subject to bare-soil evaporation, 1972-88 9

8. Simulated changes in areal distribution of model cells subject to bare-soil evaporation and drainflow, if present practices are maintained 10

9,10. Maps showing:

9. Areal distribution of model cells subject to bare-soil evaporation if present practices are maintained, 1990 and $2040 \quad 11$

10. Management units in the model area $\mathbf{1 2}$

11. Graphs showing simulated effects of land retirement in management units 1 and $2 \quad 14$

12. Maps showing changes in areal distribution of model cells subject to bare-soil evaporation as a result of land retirement 15

13. Graphs showing simulated effects of reducing recharge to 0.46 foot per year in all management units 16

14. Maps showing changes in areal distribution of model cells subject to bare-soil evaporation as a result of reducing recharge to 0.46 foot per year 17 
15. Graphs showing simulated effects of reducing recharge by 15,30 , and 45 percent in management unit $4 \quad 19$

16. Maps showing changes in areal distribution of model cells subject to bare-soil evaporation as a result of reducing recharge in management unit 420

17. Graphs showing simulated effects of increasing pumping by a constant increment from existing wells in management units 2 and 422

18. Maps showing changes in areal distribution of model cells subject to bare-soil evaporation by the year 2040 when simulating an increase in pumping by a constant increment from existing wells 23

19. Graphs showing simulated effects of increasing pumping by a variable increment from existing wells in management units 2 and 424

20. Maps showing areal distribution of variable pumping increments from existing wells in management units 2 and 425

21. Maps showing changes in areal distribution of model cells subject to bare-soil evaporation by the year 2040 when simulating an increase in pumping by a variable increment from existing wells 26

22. Graphs showing simulated effects of increasing pumping by a variable increment from the confined zone only in management units 2 and 427

23. Maps showing areal distribution of variable pumping increments from the confined zone only in management units 2 and 428

24. Maps showing changes in areal distribution of model cells subject to bare-soil evaporation by the year 2040 when simulating an increase in pumping by a variable increment from the confined zone only 29

25. Graphs showing simulated effects of the combination of reducing recharge and increasing pumping from existing wells or from the confined zone only $\mathbf{3 0}$

26. Maps showing changes in areal distribution of model cells subject to bare-soil evaporation by the year 2040 when simulating the combined effects of reducing recharge and increasing pumping from existing wells or from the confined zone only 31

27,28. Graphs showing:

27. Data provided by the U.S. Bureau of Reclamation for five management alternatives for the San Luis Unit 33

28. Simulated effects on the number of model cells subject to bare-soil evaporation for the five management alternatives proposed by the U.S. Bureau of Reclamation 35

\section{TABLES}

1. Water-budget data for 19805

2. Distribution of pumping from semiconfined and confined zones $\mathbf{5}$

3. Number of model cells with increments in pumping at specified rates and total incremental volume of pumpage for various pumping management scenarios 21

4. Water-budget data for 1991, 2007, 2025, and 2040 for that part of the San Luis Unit incorporated in the U.S. Geological Survey model 34

5. Summary of the simulated effects of management alternatives by $2040 \quad 36$

6. Changes in model cells subject to bare-soil evaporation and in drainflow for all management alternatives 40 


\begin{tabular}{rrl}
\multicolumn{1}{c}{ Multiply } & \multicolumn{1}{c}{ By } & \multicolumn{1}{c}{ To obtain } \\
\hline acre & 0.4047 & hectare \\
acre-foot per year & 1,233 & cubic meter per year \\
foot $(\mathrm{ft})$ & 0.3048 & meter \\
foot per year $(\mathrm{ft} / \mathrm{yr})$ & 0.3048 & meter per year \\
mile $(\mathrm{mi})$ & 1.609 & kilometer \\
square mile (mi $\left.{ }^{2}\right)$ & 2.590 & square kilometer \\
\hline
\end{tabular}

\section{Vertical Datum}

Sea level: In this report, "sea level" refers to the National Geodetic Vertical Datum of 1929--a geodetic datum derived from a general adjustment of the first-order level nets of the United States and Canada, formerly called Sea Level Datum of 1929. 


\title{
SIMULATION OF WATER-TABLE RESPONSE TO
}

\section{MANAGEMENT ALTERNATIVES, CENTRAL PART OF THE WESTERN SAN JOAQUIN VALLEY, CALIFORNIA}

\author{
By Kenneth Belitz and Steven P. Phillips
}

\begin{abstract}
The occurrence of selenium in agricultural drainwater in the central part of the western San Joaquin Valley, California, has focused concern on alternatives other than agricultural drains for managing shallow, poor-quality ground water. A transient, three-dimensional, finite-difference ground-water flow model was developed to assess the response of the water table to various management alternatives. The modeled area is 551 square miles and includes the semiconfined and confined zones above and below the Corcoran Clay Member of the Tulare Formation of Pleistocene age. The model was calibrated using hydrologic data from 1972 to 1988 and was able to reproduce the average change in water-table altitude to within 4 percent.
\end{abstract}

The calibrated model was extended to forecast to the year 2040 for various management alternatives including maintenance of present practices, land retirement, reduced recharge, increased ground-water pumping, combinations of these alternatives, and five alternatives proposed by the U.S. Bureau of Reclamation. The model indicates that if current rates of recharge and pumping (as determined from an analysis of 1980 water-budget data) are maintained, the total area subject to bare-soil evaporation will increase by more than 50 percent and drainflow will increase by 20 percent.

Model results indicate that retirement of land will result in a water-table decline beneath the area retired, but the effect on adjacent areas will be small to negligible. The effects of reducing recharge or increasing ground-water pumping vary with the magnitude of the change relative to average conditions and the size of the area managed. The area of land subject to bare-soil evaporation and the amount of drainflow in the model area can be reduced by more than 40 and 50 percent, respectively, if (1) recharge is reduced by 40 percent (about 0.3 foot per year) in areas that currently use only surface water, and by 15 percent (an average of about 0.1 foot per year) in the remainder of the model area; (2) pumping is increased by 0.5 foot per year in areas that currently use surface and ground water.

\section{INTRODUCTION}

Agricultural productivity in California's western San Joaquin Valley is subject to the potentially adverse effects of shallow, poor-quality ground water. Of the more than 2.2 million acres under irrigation in the western San Joaquin Valley, nearly 850,000 acres are underlain by a water table that is within $5 \mathrm{ft}$ of land surface (San Joaquin Valley Drainage Program, 1989a). Areas that are underlain by a shallow water table are prone to soil salinization and degradation of ground-water quality. Historically, subsurface tile drains have been used to control the altitude of the water table and to manage subsurface water quality. However, selenium-bearing agricultural drainwater derived from a part of the western San Joaquin Valley and exported to the Kesterson Wildlife Refuge led to deaths and deformities of waterfowl and aquatic biota (Deverel and others, 1984; Presser and Barnes, 1985; Ohlendorf and others, 1986). The occurrence of selenium toxicity at Kesterson resulted in the closure of contributing drainage facilities. In the absence of drains, there is considerable concern as to how to manage the ground-water flow system in the western San Joaquin Valley (San Joaquin Valley Drainage Program, 1989a).

A transient, three-dimensional, finite-difference ground-water flow model was developed to simulate the regional water table in an area of about $550 \mathrm{mi}^{2}$ in the central part of the western San Joaquin Valley (Phillips and Belitz, 1991; Belitz and others, 1992) (fig. 1), including the area from which seleniumbearing drainwater was collected. The boundaries of the model area were selected to coincide with hydrogeologic boundaries where possible. The western boundary is defined by the contact between the deformed rocks of the Coast Ranges and the unconsolidated deposits of the valley; the eastern boundary 


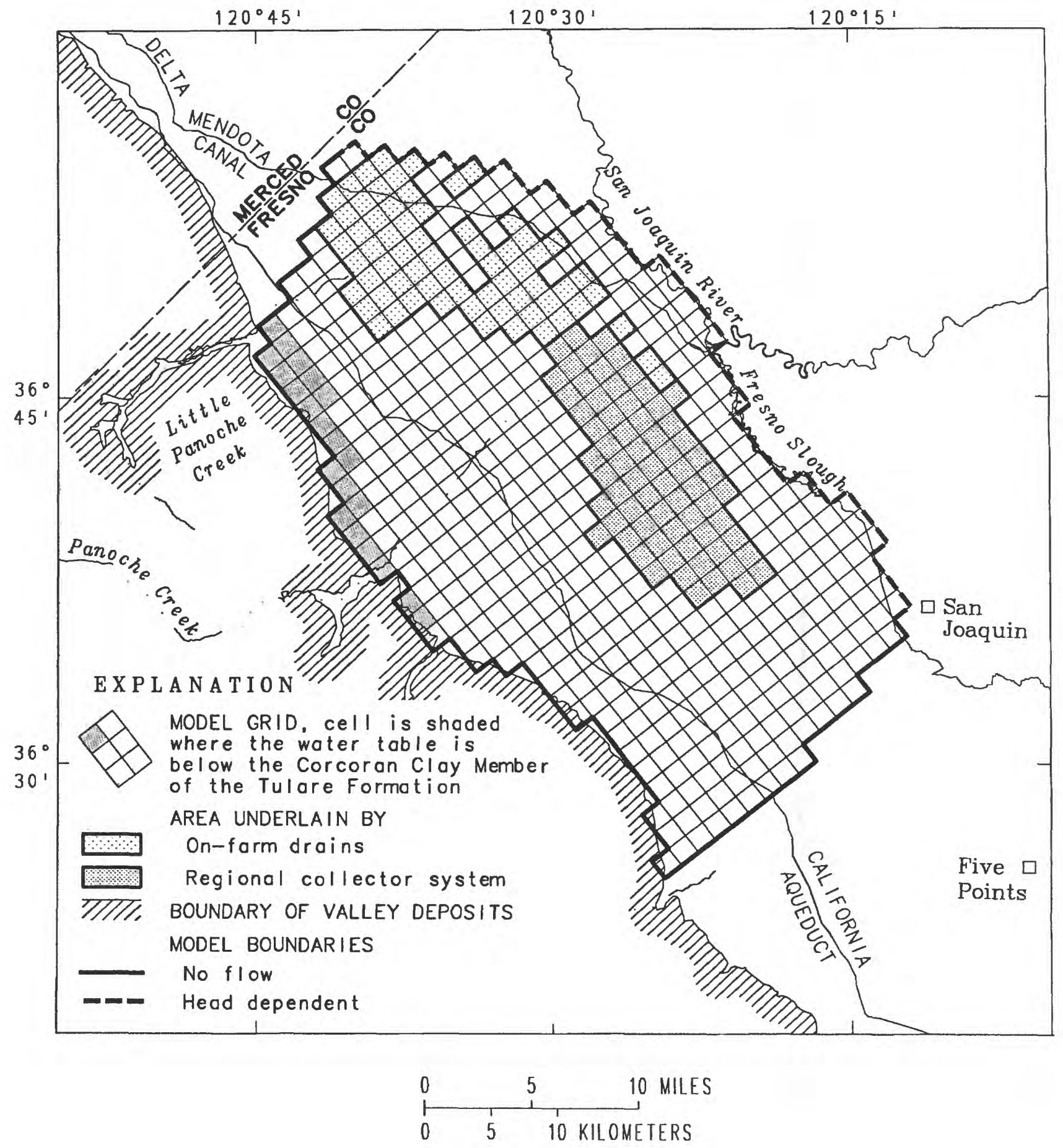

Figure 1. Model grid and lateral boundary conditions. 
is defined by the San Joaquin River and Fresno Slough, which occupy the trough of the San Joaquin Valley; the northern and southern boundaries are defined by radial lines along the Little Panoche Creek and Cantua Creek alluvial fans, respectively; and the northeastern boundary is defined approximately by the Delta-Mendota Canal, which is built along a topographic contour defining a break in slope between fan deposits and the valley trough.

This report describes the use of the model for evaluating the response of the water table to different management alternatives that affect recharge to or discharge from the ground-water flow system. The development of the model and its ability to reproduce measured hydrologic conditions are described by Phillips and Belitz (1991) and Belitz and others (1992). This study was done by the U.S. Geological Survey in cooperation with the U.S. Bureau of Reclamation.

\section{HYDROGEOLOGIC SETIING}

The central part of the western valley is underlain by the Corcoran Clay Member of the Tulare Formation of Pleistocene age, which divides the flow system into a lower confined zone and an upper semiconfined zone (fig. 2). The semiconfined zone can be divided into three hydrogeologic units: Coast Ranges alluvium, Sierran sand, and flood-basin deposits (Belitz and Heimes, 1990). The thickness of the Coast Ranges alluvium is more than $800 \mathrm{ft}$ along the Coast Ranges and thins to $0 \mathrm{ft}$ near the valley axis (Miller and others, 1971). The thickness of the Sierran sand is 400 to $500 \mathrm{ft}$ in the valley trough and thins eastward and westward (Miller and others, 1971). The thickness of the flood-plain deposits ranges from 5 to $35 \mathrm{ft}$ and overlie the Sierran sand (Laudon and Belitz, 1991). The thickness of the confined zone, defined as the interval from which ground water has been pumped historically, ranges from 570 to $2,460 \mathrm{ft}$ (Williamson and others, 1989).

Prior to 1967, most of the study area relied on ground water as the sole source of irrigation water. Since 1967, most of the study area has relied primarily on imported surface water as a source of irrigation, with ground water as an important secondary source. The long history of irrigation in the study area, combined with a reduction in ground-water pumping since 1967 , has caused a significant rise in the altitude of the water table. Consequently, more than 50 percent of the study area is presently underlain by a water table within $10 \mathrm{ft}$ of land surface. A more complete description of the character and evolution of the flow system in the central part of the western San Joaquin Valley is provided by Belitz and Heimes (1990).

\section{NUMERICAL MODEL}

A transient, three-dimensional, finite-difference model of the ground-water flow system in the central part of the western San Joaquin Valley was developed to assess the response of the water table to various management alternatives (Belitz and others, 1992). Areally, the model grid is 36 rows by 20 columns, with each cell $1 \mathrm{mi}$ on a side (fig. 1). Vertically, the semiconfined zone was divided into five layers, and the confined zone below the Corcoran Clay Member was represented by a sixth model layer. The model incorporates distributed recharge and pumping (Gronberg and Belitz, 1992), regional-collector drains in the Westlands Water District (operative from 1981 to 1985), on-farm drains in parts of the Panoche, Broadview, and Firebaugh Water Districts, and baresoil evaporation from the water table. The model was calibrated using hydrologic data from 1972 to 1988.

Recharge and pumping in the model were areally distributed but temporally constant. The areal distribution and rates of recharge and pumping were based on an analysis of 1980 water budgets in nine subareas ranging from 16 to $155 \mathrm{mi}^{2}$ (fig. 3 , table 1). Water-budget components are expressed in units of feet, which is the equivalent of acre-feet per acre. Gronberg and Belitz (1992) noted that 1980 was an average year with respect to crops planted, weather, and surface-water delivery. The vertical distribution of pumping (relation of semiconfined zone and confined zone) was based on an analysis of wellperforation data in 492 wells in 10 subareas (fig. 4, table 2) (Gronberg and Belitz, 1992). The regionalcollector drains were modeled at a depth of $10.1 \mathrm{ft}$, and the on-farm collector drains were modeled at a 

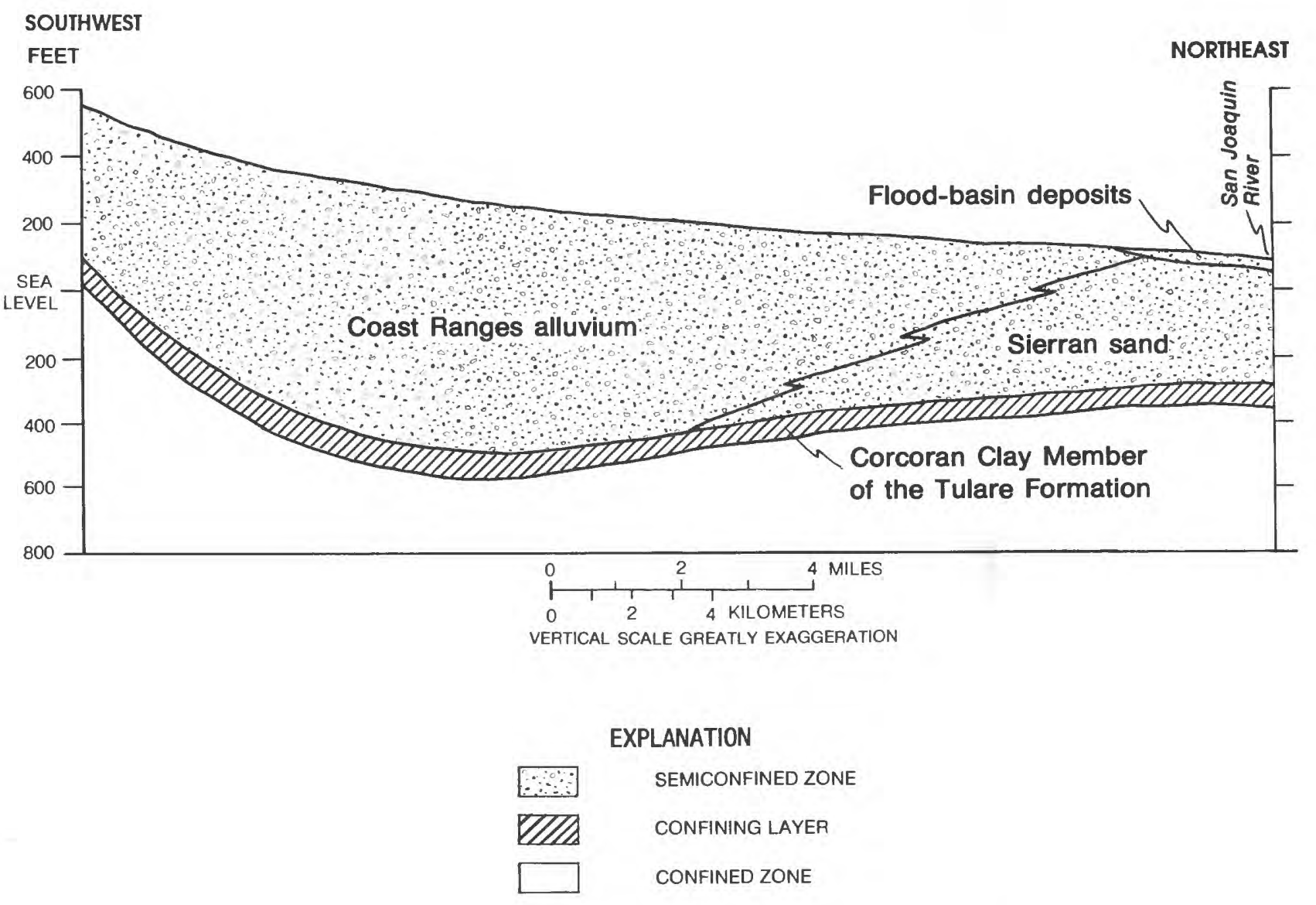

Figure 2. Generalized hydrogeologic section of the semiconfined zone perpendicular to the axis of the San Joaquin Valley. Approximate location of section is model row 18 (see figure 1).

depth of $7.3 \mathrm{ft}$; these depths were based on a regression analysis of water-level and drainage discharge data. Bare-soil evaporation in the model occurs when the water table is within $7 \mathrm{ft}$ of land surface; this depth was based on a theoretical analysis of hydraulic characteristics of Panoche clay loam.

The ability of the model to reproduce measured conditions can be evaluated by examining several measures of the state of the ground-water flow system. Figure 5 illustrates the measured and simulated depth to the water table in October 1984. The model was able to reproduce the large variation (interval, 10, 20, 50, 100, 200, and $400 \mathrm{ft}$ ) in measured depth to the water table. The eastern part of the model area is underlain by a water table within $20 \mathrm{ft}$ of land surface, and the western part is underlain by a water table more than $50 \mathrm{ft}$ below land surface. The ability of the model to reproduce the measured depth to the water table in 1984 is a consequence of the model's ability to reproduce the measured change in water-table altitude from 1972 to 1984 . Belitz and others (1992) noted that the model is able to reproduce changes averaged for large areas $\left(75 \mathrm{mi}^{2}\right)$ better than for small areas $\left(25 \mathrm{mi}^{2}\right)$.

Areal distribution of year round and seasonal measured and simulated number of model cells subject to bare-soil evaporation (defined as areas with a water table within $7 \mathrm{ft}$ of land surface) in 1984 is shown in figure 6. 
Table 1. Water-budget data for 1980 (modified from table 5. Gronberg and Belitz, 1992)

[Irrigation efficiency from worksheets. ft, foot; nc, not calculated]

\begin{tabular}{|c|c|c|c|c|c|c|c|}
\hline Subarea & $\begin{array}{l}\text { Crop } \\
\text { water } \\
\text { require- } \\
\text { ment } \\
\text { (ft) }\end{array}$ & $\begin{array}{l}\text { Irrigation } \\
\text { efficiency } \\
\text { based on } \\
\text { depth to } \\
\text { water table } \\
\text { (percent) }\end{array}$ & $\begin{array}{l}\text { Irrigation } \\
\text { require- } \\
\text { ment } \\
\text { (ft) }\end{array}$ & $\begin{array}{l}\text { Surface- } \\
\text { water } \\
\text { delivery } \\
\text { (ft) }\end{array}$ & $\begin{array}{l}\text { Ground- } \\
\text { water } \\
\text { pumpage } \\
\text { (ft) }\end{array}$ & $\begin{array}{l}\text { Ground- } \\
\text { water } \\
\text { recharge } \\
\text { (ft) }\end{array}$ & $\begin{array}{l}\text { Irrigation } \\
\text { efficiency } \\
\text { based on } \\
\text { application } \\
\text { (percent) }\end{array}$ \\
\hline Firebaugh $\ldots \ldots \ldots \ldots \ldots$ & $\ldots 1.88$ & 80 & 2.35 & 2.63 & 0 & 0.75 & 70 \\
\hline Tranquillity $\ldots \ldots \ldots \ldots \ldots \ldots$ & $\ldots \ldots 1.97$ & 70 & 2.81 & 2.51 & .30 & .84 & $\mathrm{nc}$ \\
\hline Panoche $\ldots \ldots \ldots \ldots \ldots \ldots$ & $\ldots 1.52$ & 73 & 2.08 & 2.48 & 0 & .96 & 61 \\
\hline Broadview $\ldots \ldots \ldots \ldots \ldots \ldots$ & $\ldots . .97$ & 79 & 2.49 & 2.75 & 0 & .78 & 72 \\
\hline San Luis $\ldots \ldots \ldots \ldots \ldots$ & $\ldots 1.47$ & 65 & 2.26 & 1.86 & .40 & .79 & $\mathrm{nc}$ \\
\hline \multicolumn{8}{|l|}{ Westlands } \\
\hline \multicolumn{8}{|l|}{ Depth to water table } \\
\hline $\begin{array}{l}\text { Less than or equal to } 10 \mathrm{ft} \ldots \\
\text { Greater than } 10 \mathrm{ft} \text { and less }\end{array}$ & $\ldots 1.84$ & 80 & 2.30 & 1.90 & .40 & .46 & nc \\
\hline than or equal to $20 \mathrm{ft} \ldots$ & $\ldots 1.91$ & 72 & 2.65 & 2.19 & .46 & .74 & nc \\
\hline \multicolumn{8}{|l|}{ Greater than $20 \mathrm{ft}$} \\
\hline $\begin{array}{l}\text { With surface-water delivery } \\
\text { Without surface-water }\end{array}$ & $\ldots 1.74$ & 65 & 2.68 & 2.43 & .25 & .94 & nc \\
\hline delivery . . . . . . . . & $\ldots 1.60$ & 65 & 2.46 & 0 & 2.46 & .86 & nc \\
\hline
\end{tabular}

Table 2. Distribution of pumping from semiconfined and confined zones (modified from Gronberg and Belitz, 1992)

\begin{tabular}{|c|c|c|c|}
\hline \multirow[b]{2}{*}{ Subarea } & \multirow[b]{2}{*}{$\begin{array}{l}\text { Sierran } \\
\text { sand }\end{array}$} & \multicolumn{2}{|c|}{ Percentage of pumping } \\
\hline & & $\begin{array}{c}\text { Semi- } \\
\text { confined }\end{array}$ & Confined \\
\hline Firebaugh $\ldots . .$. & . Present & 95 & 5 \\
\hline Tranquillity . . . . . . & . Present & 73 & 27 \\
\hline Panoche $\ldots \ldots \ldots$ & . Absent & 2 & 98 \\
\hline Broadview ...... & . Present & 18 & 82 \\
\hline San Luis ${ }^{1} \ldots .$. & - Absent & 5 & 95 \\
\hline \multicolumn{4}{|l|}{ Westlands $^{1}$} \\
\hline North .. & Present & 35 & 65 \\
\hline Middle...... & . Present & 30 & 70 \\
\hline South ....... & - Present & 63 & 37 \\
\hline \multicolumn{3}{|l|}{ With surface-water } & 94 \\
\hline Without surface- & & & \\
\hline water delivery & . Absent & 5 & 95 \\
\hline
\end{tabular}

The model reproduces 95 of the 122 cells subject to bare-soil evaporation in July and October (represents year round), 31 of the 86 cells subject to bare-soil evaporation in July or October (represents seasonal), and predicts 36 cells subject to bare-soil evaporation that were not subject to bare-soil evaporation. Thus, it appears that the model is better able to predict bare-soil evaporation on a year-round basis than on a seasonal basis.

Figure 7 is a time-series record (1972-88) of the number of model cells subject to bare-soil evaporation for measured and simulated conditions. The measured evaporation is at a maximum in July during the irrigation season and at a minimum in October after the harvest. The simulated evaporation is most consistent with the measured evaporation from 1972 to 1985 and least consistent from 1986 to 1988 . Overall, simulated evaporation is within the bounds of the measured evaporation during the period of simulation. A more complete description of the model and its ability to reproduce conditions is described by Belitz and others (1992). 


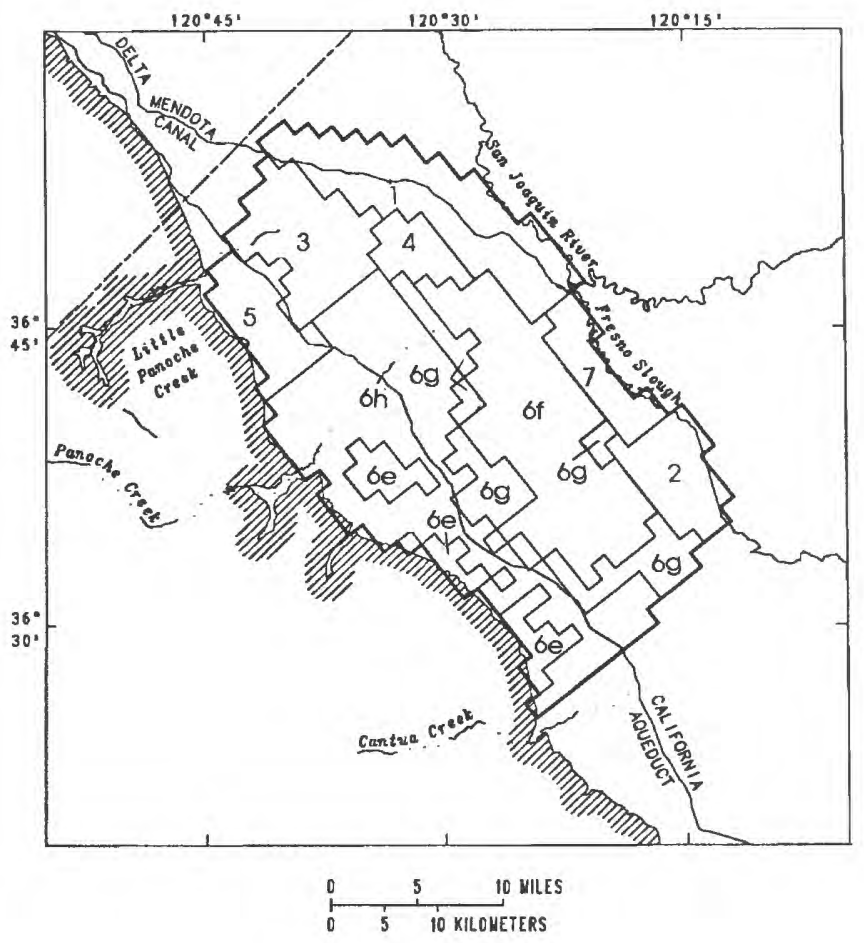

EXPLANATION

WATER-BUDGET SUBAREAS

1 Firebaugh

2 Tranquillity

3 Panoche

4 Broadview

5 San Luis

6 Westlands

Depth to water table

6f Less than or equal to $10 \mathrm{ft}$

$6 \mathrm{~g}$ Greater than $10 \mathrm{ft}$ and less than or equal to $20 \mathrm{ft}$

Greater than $20 \mathrm{ft}$

$6 \mathrm{~h}$ With surface-water delivery

6e Without surface-water delivery

7 Mendota Wildlife Refuge

\section{BOUNDARIES}

TIIIIII, Valley deposits

Model

Subarea

Figure 3. Water-budget subarea boundaries.

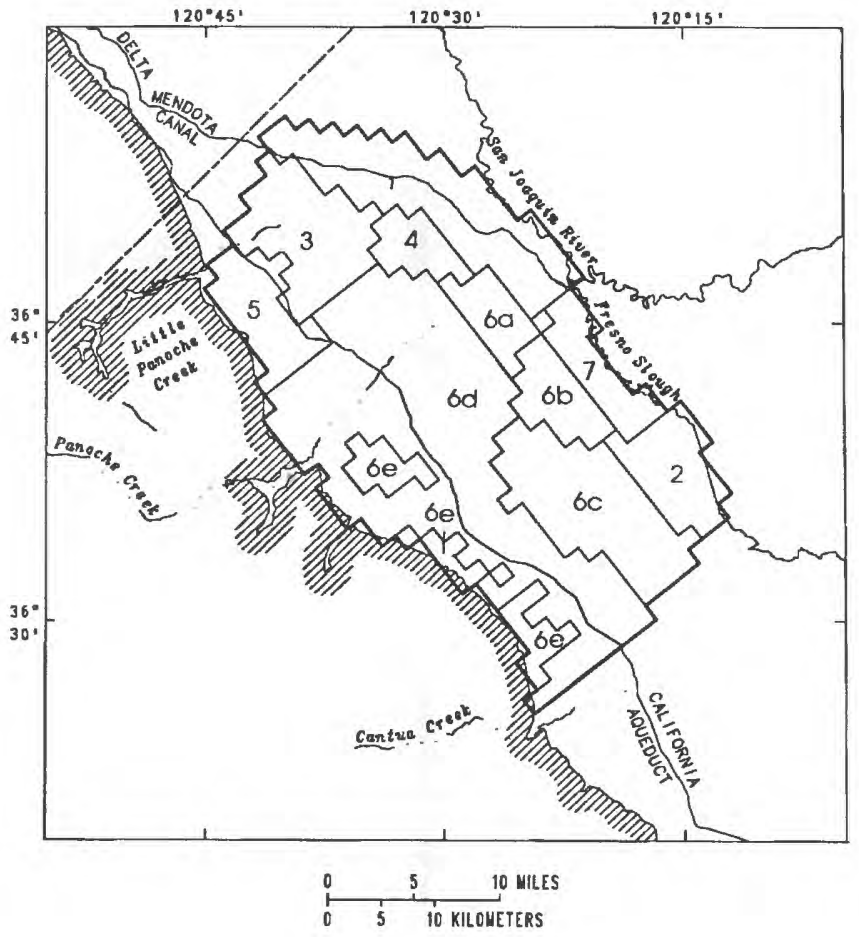

EXPLANATION

PUMPING SUBAREAS

1 Firebaugh

2 Tranquillity

3 Panoche

4 Broadview

5 San Luis

6 Westlands

Sierran sand present

6a North

$6 \mathrm{~b}$ Middle

6c South

Sierran sand absent

$6 \mathrm{~h}$ With surface-water delivery

$6 \mathrm{e}$ Without surface-water delivery

7 Mendota Wildlife Refuge

\section{BOUNDARIES}

पTITIII/. Valley deposits

- Model

- Subarea

Figure 4. Subareas used for evaluating vertical distribution of ground-water pumpage. 


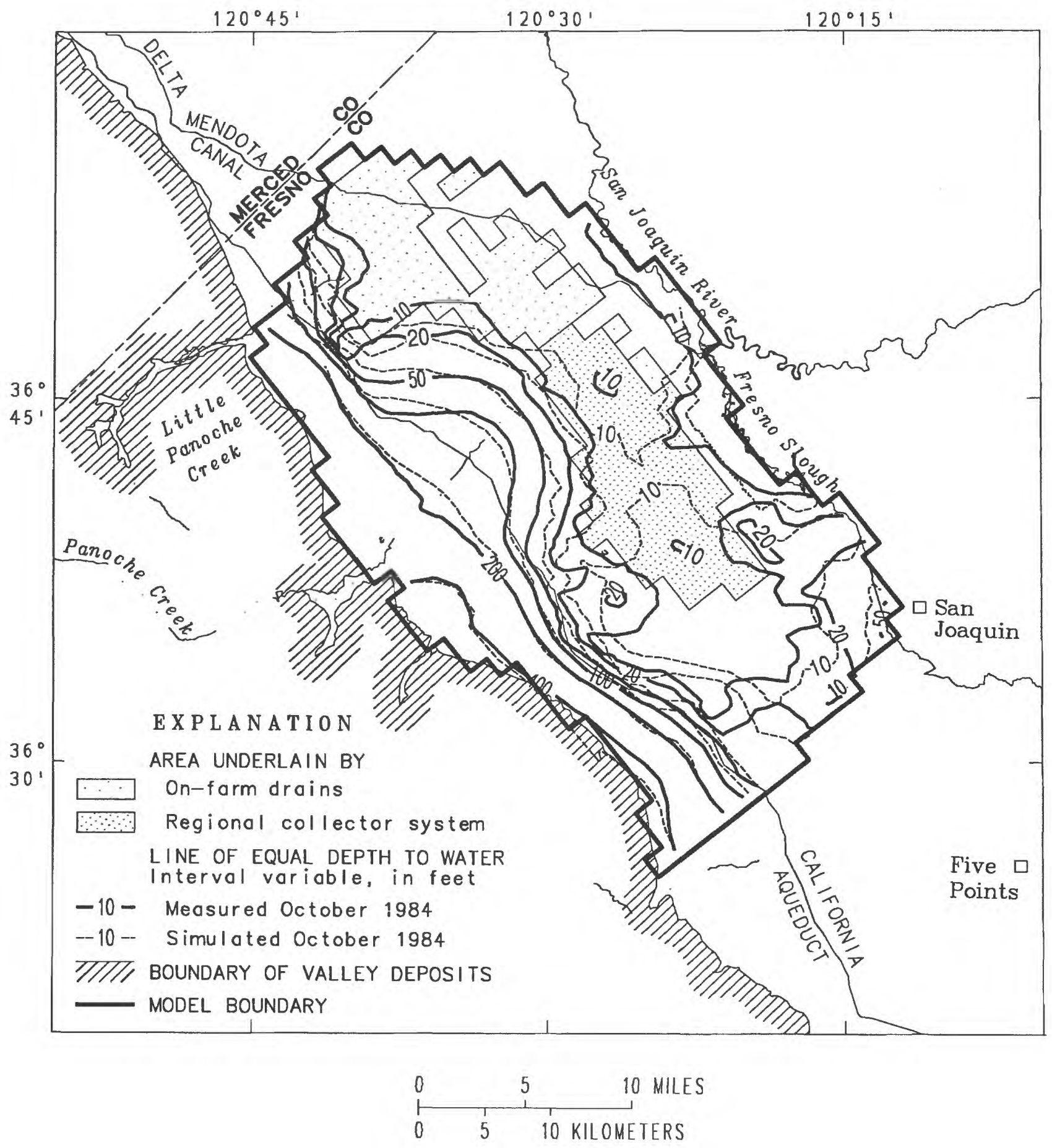

Figure 5. Measured and simulated depth to water, October 1984. 

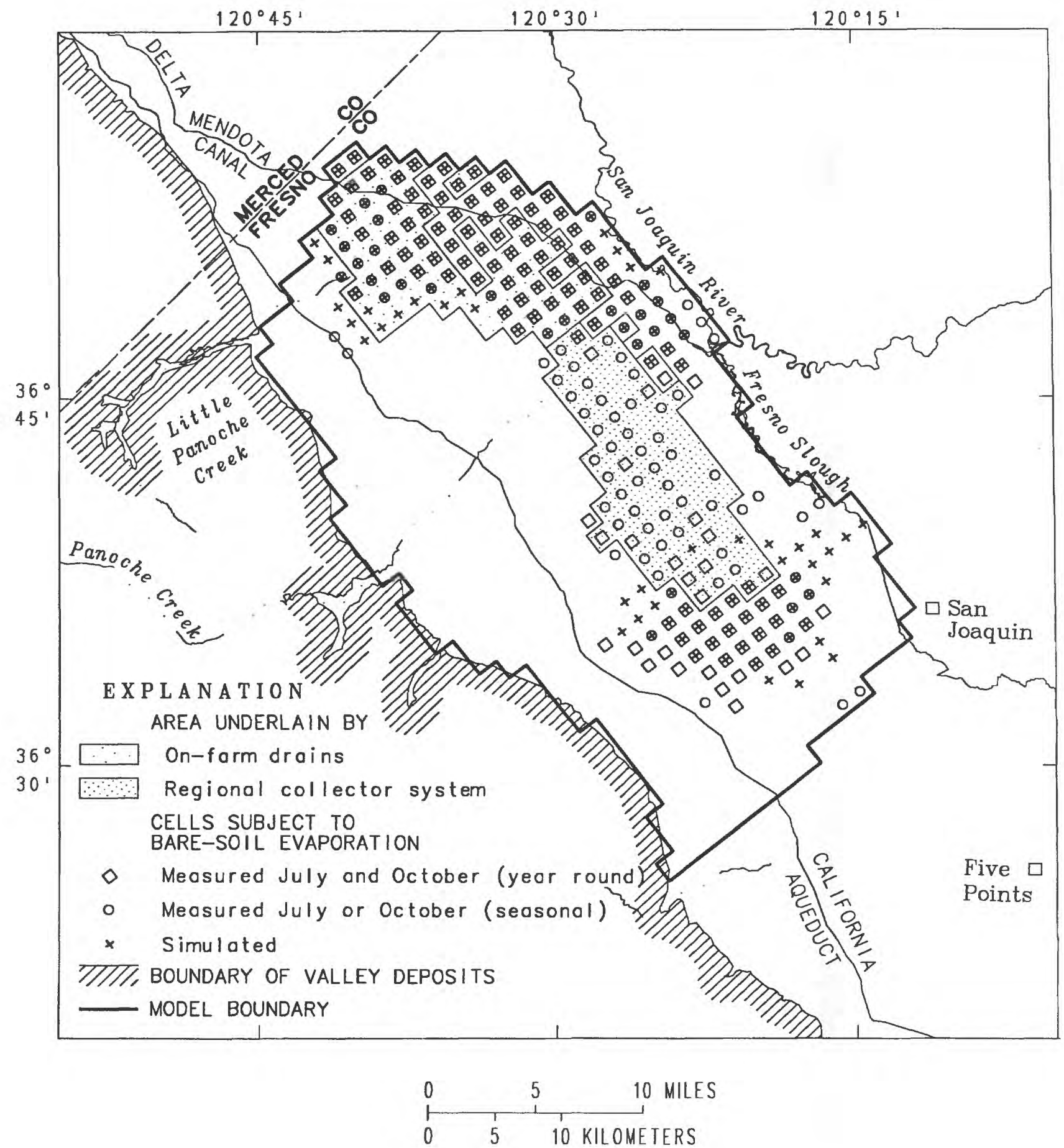

Figure 6. Areal distribution of year round and seasonal measured and simulated number of model cells subject to bare-soil evaporation, 1984. 


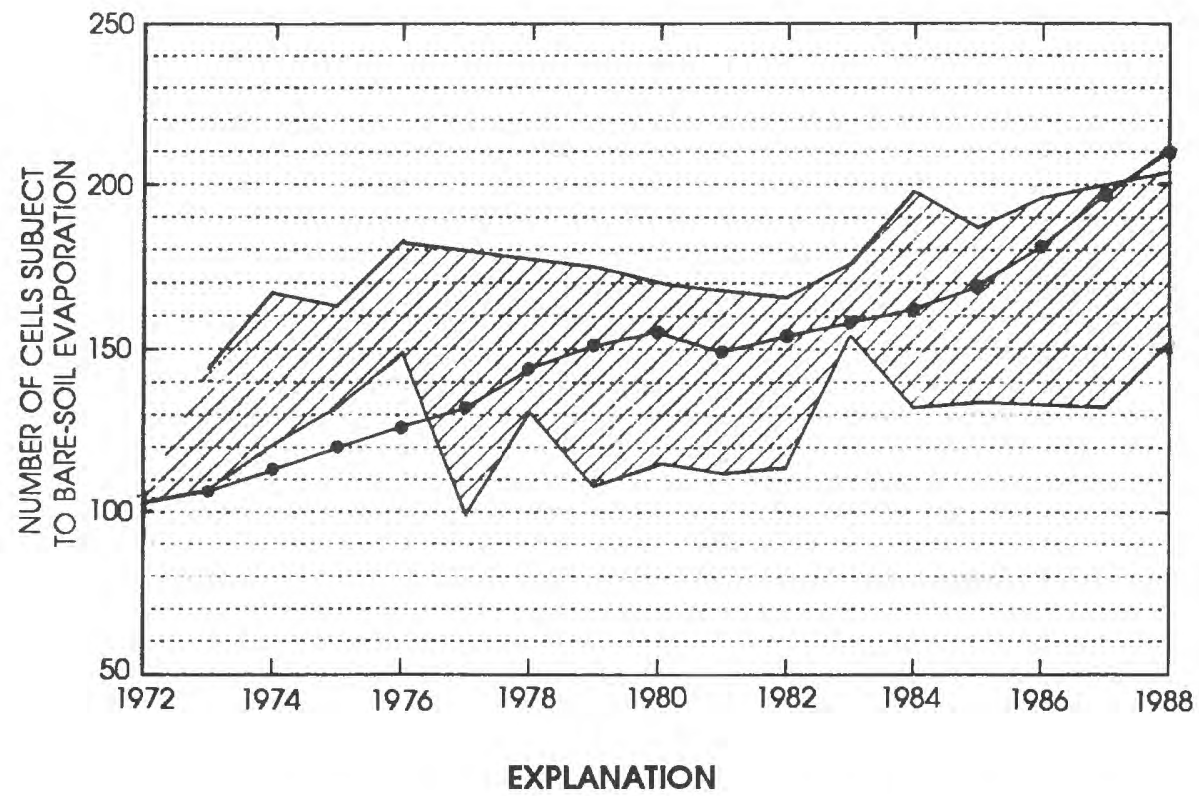

NUMBER OF CELLS SUBJECT TO BARE-SOIL EVAPORATION

QIZA Range of measured data for July and October

- Simulated

Figure 7. Measured and simulated number of model cells subject to baresoil evaporation, 1972-88.

\section{SIMULATION OF WATER-TABLE RESPONSE TO MANAGEMENT ALTERNATIVES}

The three-dimensional model developed by Belitz and others (1992) was used to evaluate the response of the water table to various management alternatives that affect recharge to or discharge from the ground-water flow system. The institutional or economic feasibility of the various alternatives and the institutional or economic responses to changes in hydrologic conditions are not accounted for in the model. In addition, the distribution of solutes in the system and the redistribution of solutes that might occur as a result of the various management alternatives are not accounted for in the model.
The purpose of the assessment was primarily to evaluate the sensitivity of the altitude of the water table to different hydrologic stresses (for example, changes in recharge rates or pumping rates). The effects of the various alternatives were quantified in terms of the number and distribution of model cells subject to bare-soil evaporation (which occurs when the water table is within $7 \mathrm{ft}$ of land surface) and by drainflow in the area of on-farm drains (which is a function of the difference between the altitude of the water table and the altitude of the drains). The existence of bare-soil evaporation is of concern because of the potential for salinization of soils and degradation of ground-water quality. Drainflow is of concern because of the problems associated with disposal of poor-quality water. For the purposes of evaluation, 1990 was selected as the year in which the various alternatives might be implemented. 


\section{MAINTENANCE OF PRESENT PRACTICES}

Maintenance of present practices is used as a basis against which other alternatives are compared. Maintenance of present practices was defined as continuation of the areally distributed, but temporally constant rates of recharge and pumping that were specified in the calibration of the model. Recharge and pumping rates were based on a water-budget analysis for an average year (1980) in terms of climate, surface-water delivery, and crop type (Gronberg and Belitz, 1992). The on-farm drains in the north were operative and the regional-collector drains in the south were inoperative during the period of simulation. The effect of maintaining present practices was assessed by simulating the water-table response on an annual basis from 1988 to 1990 , and then on a 10-year basis to 2040. The initial condition for the simulation was the 1988 head distribution simulated by the calibrated model. The model indicates that the number of model cells subject to bare-soil evaporation is 224 in 1990, 279 in 2000, and 344 in 2040 (fig. 8). Drainflow in the area of on-farm drains is $0.58 \mathrm{ft} / \mathrm{yr}$ in $1990,0.61 \mathrm{ft} / \mathrm{yr}$ in 2000, and $0.65 \mathrm{ft} / \mathrm{yr}$ in 2040 (fig. 8). Figures 8 and 9 (the areal distribution of model cells subject to baresoil evaporation) indicate that if present practices are maintained, more than one-half of the model area will be subject to bare-soil evaporation by the year 2000 and more than two-thirds by 2040 . These numbers should be viewed as a basis for evaluating the effectiveness of various management alternatives and not as a precise prediction of the state of the groundwater flow system at a particular time.

In order to assess the effects of management alternatives on the altitude of the water table, four management units were identified (fig. 10): (1) All model cells subject to bare-soil evaporation in 1990 , except those in the area underlain by on-farm drains (158 cells); (2) all model cells subject to bare-soil evaporation in 1990 (224 cells); (3) all model cells where the water table is within $100 \mathrm{ft}$ of land surface in 1990 (409 cells), which approximately coincides with areas east of the ground-water flow divide (see Belitz and Heimes, fig. 23, 1990); and (4) all model cells where the water table is above the Corcoran Clay Member (530 cells). Management units 1 and 2 are areas currently subject to bare-soil evaporation (as indicated by the model). Differentiation of units 1 and 2 allowed the evaluation of potential differences in the response of the water table in areas with and without drains. Management unit 3 was differentiated from management unit 4 because the ground-water divide has been identified as a potential boundary for management purposes. In general, the selection of management units of various sizes allowed the evaluation of the response of the water table in areas being managed and in adjacent areas not being managed.

For the purposes of discussion, model results are displayed in two formats: time-series graphs (19902040) of the number of model cells subject to baresoil evaporation and of drainflow, and maps illustrating the areal distribution of model cells subject to evaporation in 2040 . For the purposes of analysis, one can distinguish between model cells subject to evaporation in 1990 and model cells not subject to evaporation in 1990 . On that basis, one can define the "growth in evaporation" as those cells subject to
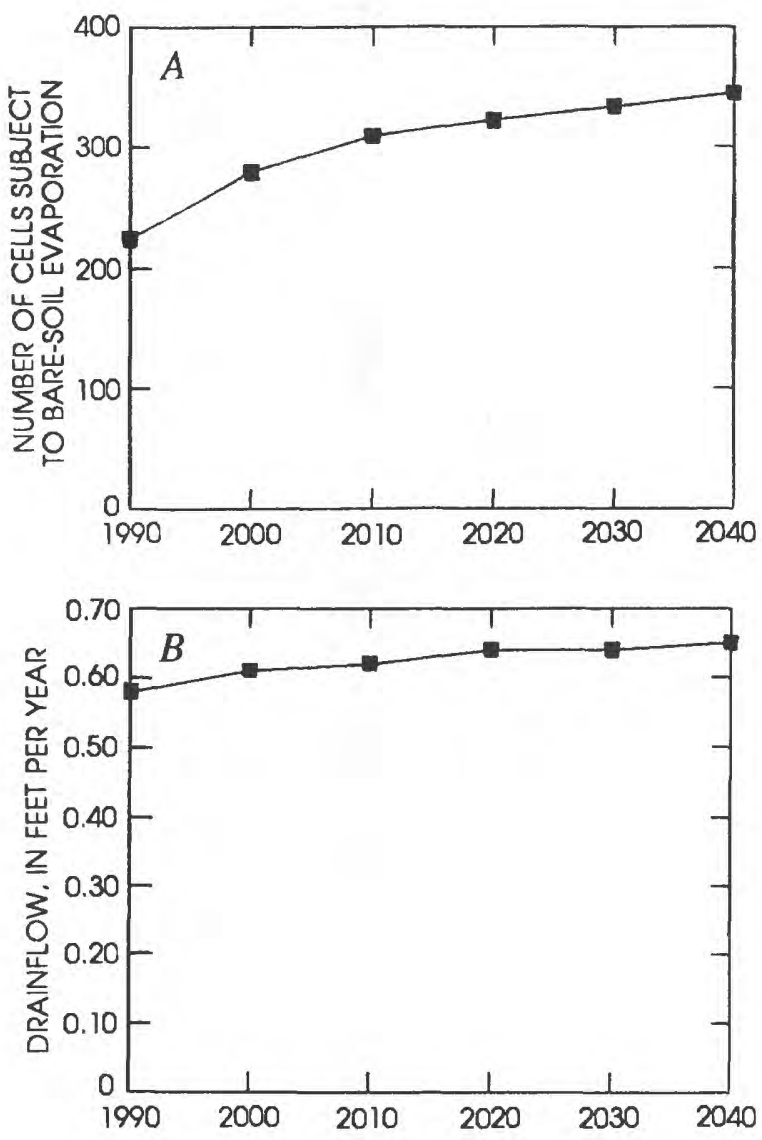

Figure 8. Simulated changes in $(A)$ areal distribution of model cells subject to bare-soil evaporation and $(B)$ drainflow, if present practices are maintained. 


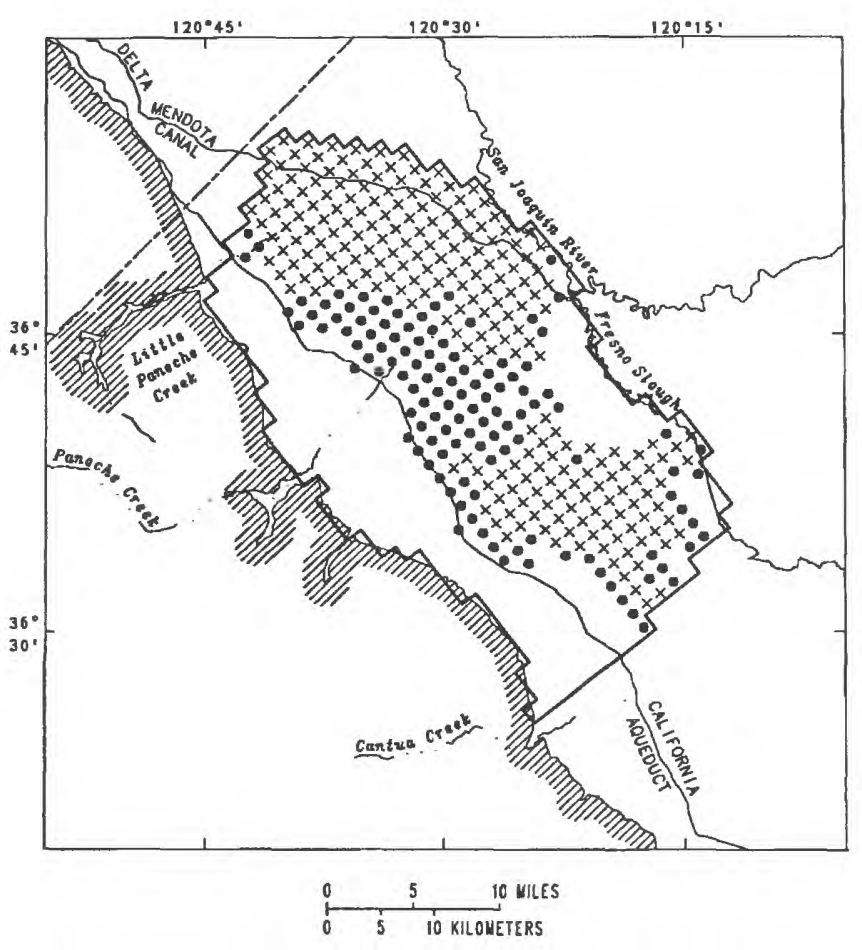

EXPLANATION

YIIIIIII, BOUNDARY OF VALLEY DEPOSITS

MODEL BOUNDARY

$\times$ CELLS SUBJECT TO BARE-SOIL EVAPORATION IN 1990

- ADditional CELLS SUBJECT TO BARESOIL EVAPORATION BY 2040

Figure 9. Areal distribution of model cells subject to bare-soil evaporation if present practices are maintained, 1990 and 2040.

evaporation in years 2000-2040 that were not subject to evaporation in 1990. One can also define the "elimination of evaporation" as those cells subject to evaporation in 1990 that are no longer subject to evaporation from 2000 to 2040 . Finally, one can also account for the total number of cells subject to baresoil evaporation.

The time-series graphs of bare-soil evaporation are of three types: (1) growth in model cells subject to evaporation, (2) elimination of model cells subject to evaporation, and (3) total number of model cells subject to evaporation. For the purposes of comparison, the results of maintaining present practices are plotted on the time-series graphs. The data that are plotted on the time-series graphs are also tabulated in table 6 (at back of report).

The maps of bare-soil evaporation are referenced with respect to the distribution of model cells subject to bare-soil evaporation in 1990. The maps illustrate: (1) cells subject to evaporation in 1990 that remain subject to evaporation in 2040; (2) additional cells subject to evaporation that were not subject to evaporation in 1990; and (3) elimination of cells subject to evaporation in 1990. The management units range in size from 158 to $530 \mathrm{mi}^{2}$, and there are variations in the certainty of model input parameters and the scale at which they are estimated; therefore, the location of cells subject to evaporation should not be taken as a precise prediction. Rather, the maps should be viewed as illustrative of trends that might occur as a consequence of various management activities.

\section{LAND RETIREMENT}

Land retirement or removal of land from agricultural production, particularly in areas with saline soils and/or underlain by poor-quality ground water, has been cited as a potential management alternative (San Joaquin Valley Drainage Program, 1989a). Land retirement was implemented in the model by specifying zero recharge and zero pumping in those cells retired; all other aspects of the model remained unchanged. Specifying zero recharge implies that there is no natural recharge. Davis and Poland (1957) and subsequent workers assumed that under natural conditions rainfall was an insignificant mechanism for recharge. Natural recharge was primarily from infiltration of stream water from intermittent streams (Belitz and Heimes, 1990). These intermittent streams do not flow through the lands being considered for retirement; therefore, natural recharge was assumed to be insignificant on retired lands.

The effect of land retirement on bare-soil evaporation and drainflow was evaluated by retiring: (1) all cells within management unit 1 ; (2) all cells within management unit 2 ; (3) all cells in the western part of management unit 2; and (4) every other cell in management unit 2 . 

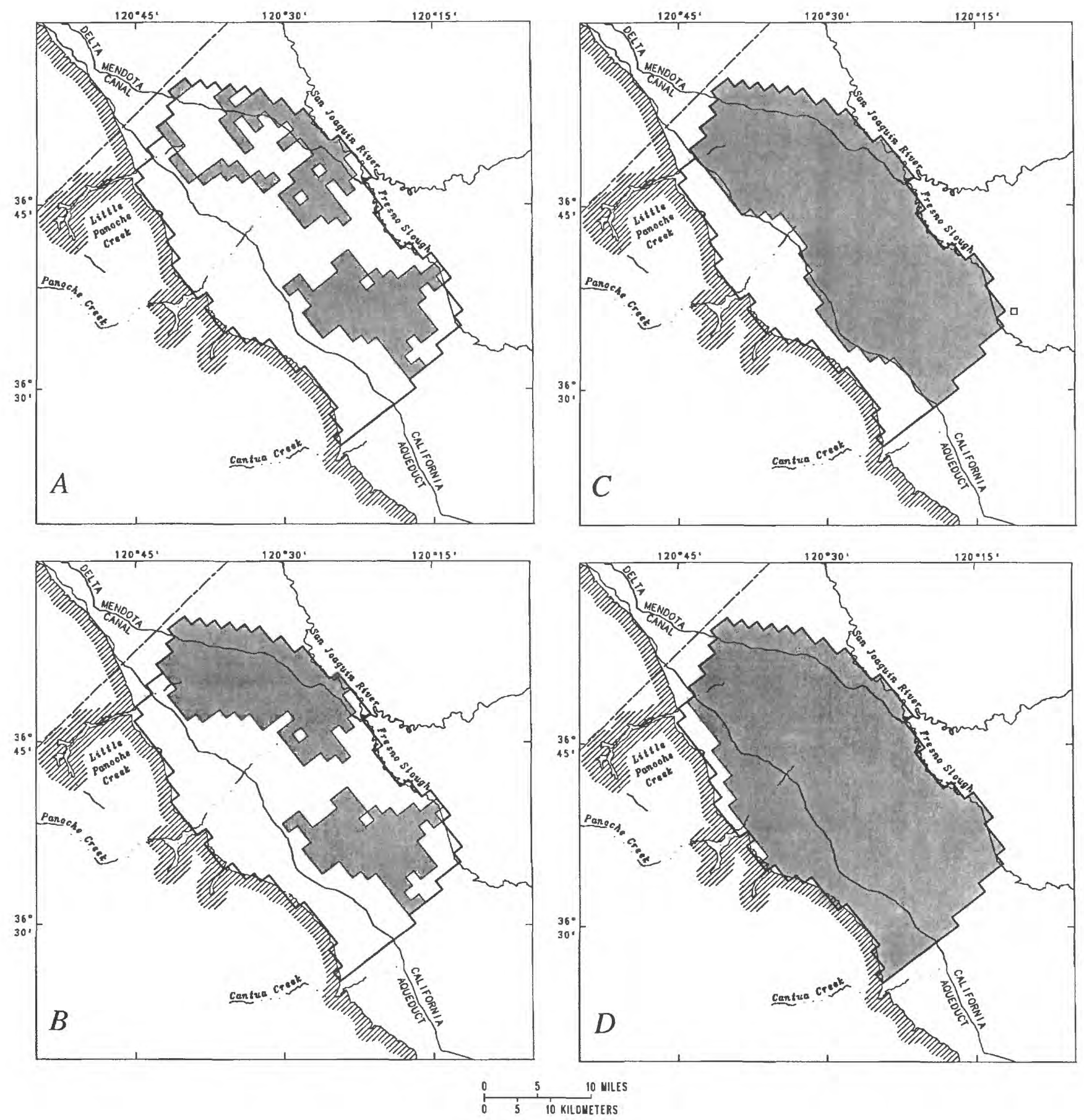

EXPLANATION

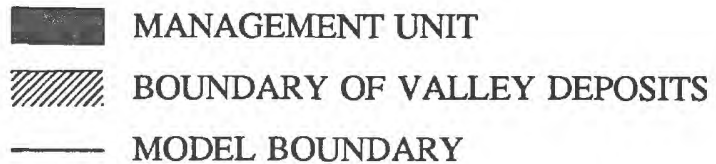

Figure 10. Management units in the model area. A, Management unit 1 . All model cells subject to baresoil evaporation in 1990 except those in the area underlain by on-farm drains. B. Management unit 2. All model cells subject to bare-soil evaporation in 1990. C. Management unit 3. All model cells east of the ground-water flow divide. D. Management unit 4. All model cells where the water table is above the Corcoran Clay Member of the Tulare Formation. 
For all four scenarios evaluated for land retirement, bare-soil evaporation was eliminated in all retired cells and there was a small to modest effect on cells not retired. The growth in the number of cells subject to bare-soil evaporation is similar to that of maintaining present practices for all four scenarios (fig. 11A). For example, if all cells subject to bare-soil evaporation in 1990 are retired, the model indicates an additional 107 cells subject to bare-soil evaporation by the year 2040, as compared with 120 cells that would have been added had present practices been maintained. Note that the additional cells subject to bare-soil evaporation are primarily upslope of the areas retired, and retirement has little effect on the upslope areas (fig. 12). Retirement of all cells in the western part of management unit 2 has little effect on the occurrence of bare-soil evaporation downslope (fig. 12). The differences in the four curves of figure $11 B$ (elimination of cells subject to bare-soil evaporation) and the five curves of figure $11 C$ (total number of cells subject to bare-soil evaporation) largely reflect the differences in the number of cells retired. The model results indicate that land retirement is an effective means for preserving land from additional salinization, but it is not particularly effective in eliminating bare-soil evaporation in adjacent areas.

Figure $11 D$ is a graph of drainflow in the area of on-farm drains for the four different retirement scenarios and for the alternative in which present practices are maintained. Retirement of management unit 1 (cells subject to bare-soil evaporation in 1990, except for those in the area of on-farm drains) results in a reduction of drainflow of less than 10 percent, relative to maintaining present practices. If the drained area also is retired (retirement of management unit 2), then drainflow is reduced to zero. Retirement of the western part of management unit 2 or every other cell in management unit 2 reduces drainflow in proportion to the number of drainflow cells retired.

\section{IMPROVEMENT IN IRRIGATION EFFICIENCY}

\section{REDUCE RECHARGE TO 0.46 FOOT PER YEAR}

Improvements in irrigation efficiency will allow less irrigation water to be applied. If the reduction in application is accompanied by a reduction in surfacewater delivery, improvements in efficiency will result in a reduction of ground-water recharge. A preliminary assessment of the effects of improvements in irrigation efficiency was made by using a recharge rate of $0.46 \mathrm{ft} / \mathrm{yr}$ in all four management units and maintaining current pumping rates (table 1). A recharge rate of $0.46 \mathrm{ft} / \mathrm{yr}$ is based on the lowest estimated rate in the study area and would require significant, and perhaps unrealistic improvements in irrigation efficiency in some areas. A substantial part of the area subject to bare-soil evaporation in 1990 already has a recharge rate of $0.46 \mathrm{ft} / \mathrm{yr}$. Aside from changes in recharge rate, all other aspects of the model remained identical to the calibrated model.

The effects of improving irrigation efficiency such that recharge is reduced to $0.46 \mathrm{ft} / \mathrm{yr}$ are illustrated in figures 13 and 14 . The growth in cells subject to bare-soil evaporation (fig. 13A) indicates that if recharge reduction is limited to management units 1 or 2 , the growth in bare-soil evaporation will be similar to that of maintaining present practices. If, however, recharge reduction is extended to management unit 3, the growth can be limited to less than 40 cells. If recharge reduction is extended to management unit 4, the growth can be limited to less than 20 cells. The model results for this altemative indicate that avoidance of growth in cells subject to bare-soil evaporation requires recharge reduction in cells not presently subject to bare-soil evaporation.

The elimination of cells subject to bare-soil evaporation (fig. 13B) indicates that the number of cells eliminated is affected by the size of the area in which recharge is reduced and that the reduction in bare-soil evaporation is greatest in the year 2000 and decreases thereafter. Figure $13 B$ can be used, to some extent, to evaluate the effect of upslope irrigation on the areal extent of downslope bare-soil evaporation. The model indicates that the number of cells subject to bare-soil evaporation in 1990 is 224 (fig. 13C). If recharge in that area is uniformly reduced to 0.46 $\mathrm{ft} / \mathrm{yr}, 27$ of those cells will not be subject to bare-soil evaporation in the year 2040 (197 cells would remain). If recharge is uniformly reduced to 0.46 $\mathrm{ft} / \mathrm{yr}$ in management unit 4 (530 cells), 54 of the cells subject to bare-soil evaporation in 1990 would not be subject to bare-soil evaporation in the year 2040 (170 cells would remain).

The total number of cells subject to bare-soil evaporation from 1990 to 2040 (fig. 13C), and the areal distribution of cells subject to bare-soil evaporation in 2040 (fig. 14) indicate that if recharge reduction is limited to management units 1 or 2 , the total number of cells subject to bare-soil evaporation will increase substantially with time. If recharge reduction is extended to management unit 3 , the total number of cells subject to bare-soil evaporation will 

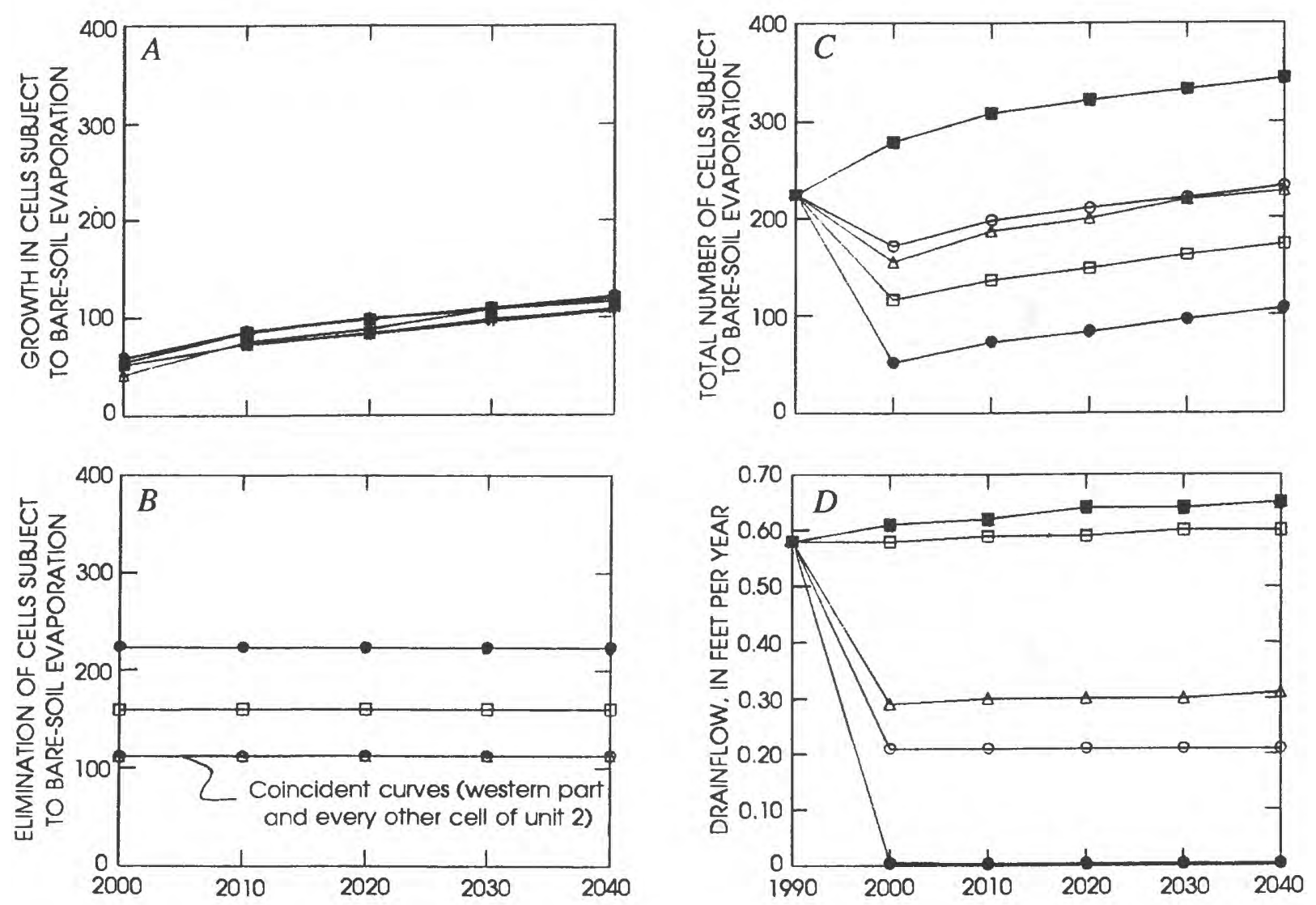

\section{EXPLANATION}

- MAINTAIN PRESENT PRACTICES

LAND RETIREMENT IN MANAGEMENT UNITS

- Unit 1

- Unit 2

- Unit 2, western part of unit 2

$\triangle \quad$ Unit 2, every other cell of unit 2

Figure 11. Simulated effects of land retirement in management units 1 and 2. 

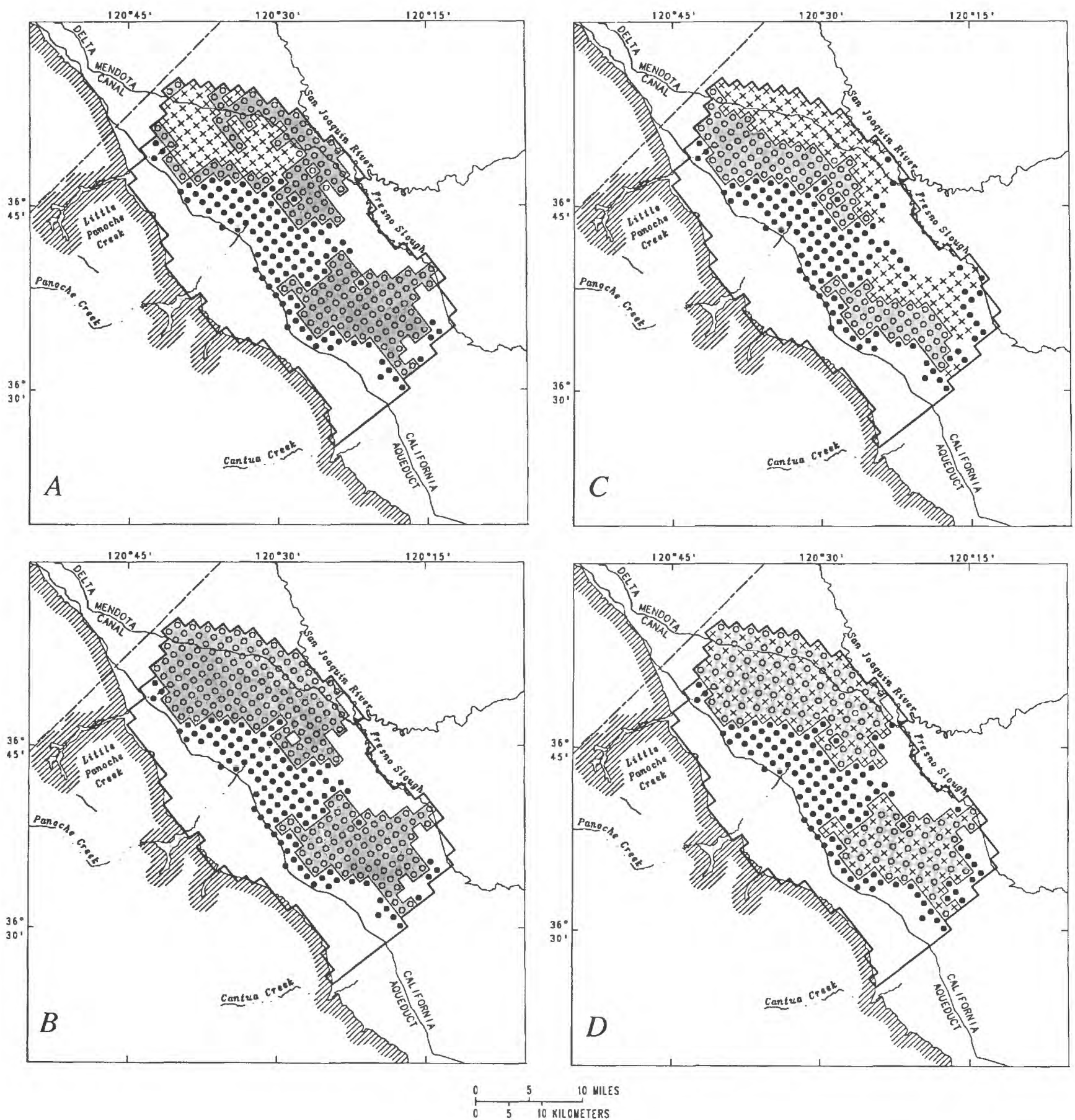

EXPLANATION
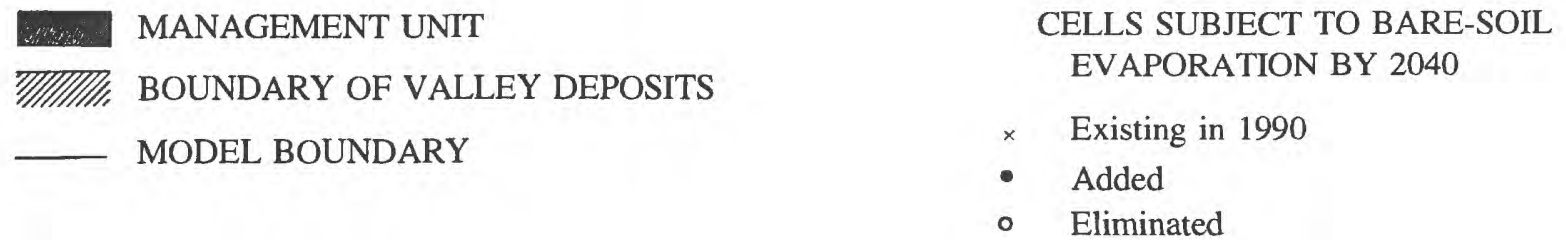

Figure 12. Changes in areal distribution of model cells subject to bare-soil evaporation as a result of land retirement. $A$, Land retirement in management unit 1. B, Land retirement in management unit 2. C, Land retirement in the western part of management unit 2. D. Land retirement in every other cell of management unit 2. 

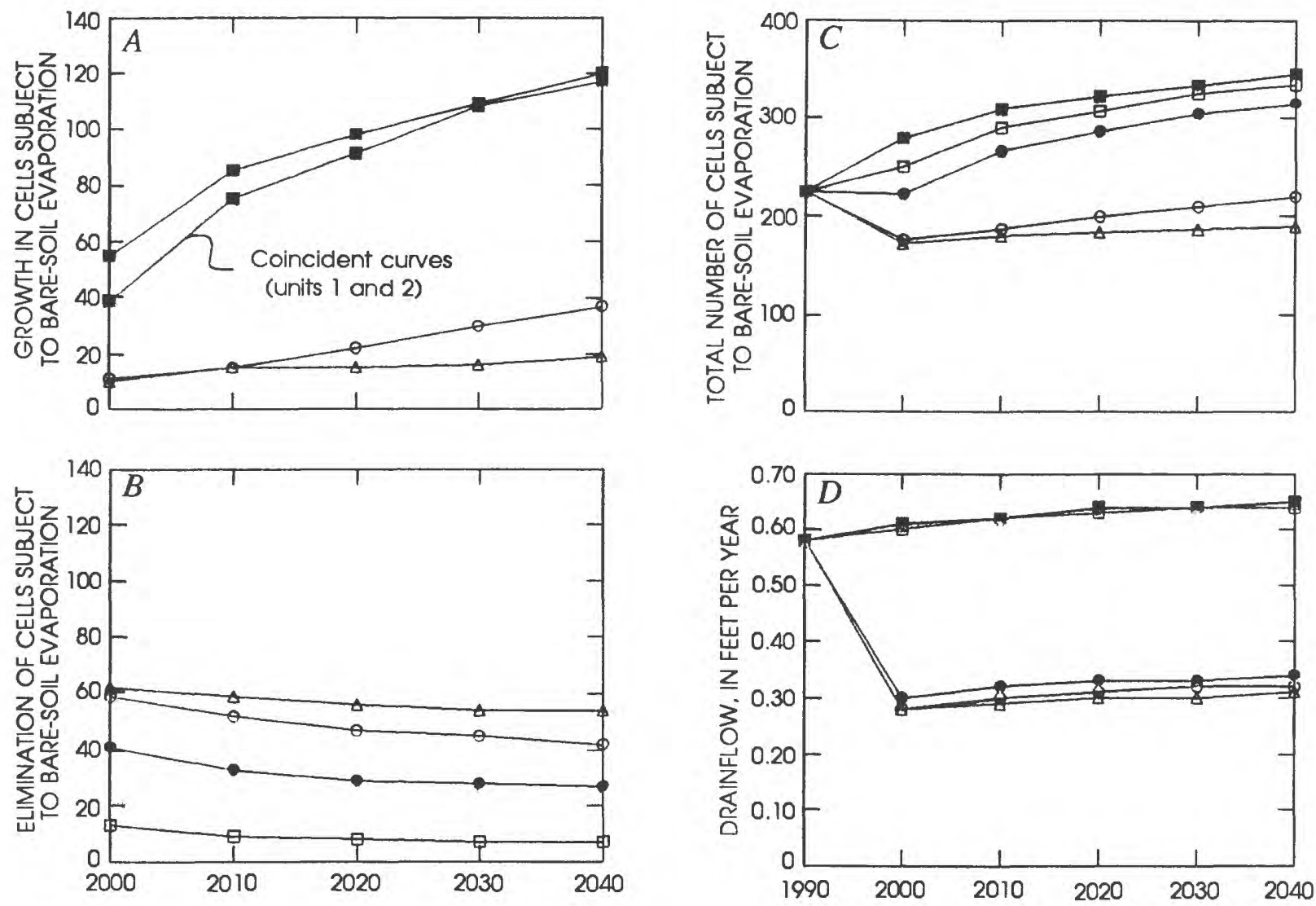

\section{EXPLANATION}

- MAINTAIN PRESENT PRACTICES

REDUCTION OF RECHARGE TO 0.46 FOOT PER YEAR IN MANAGEMENT UNITS

- Unit 1

- Unit 2

- Unit 3

$\Delta \quad$ Unit 4

Figure 13. Simulated effects of reducing recharge to 0.46 foot per year in all management units. 

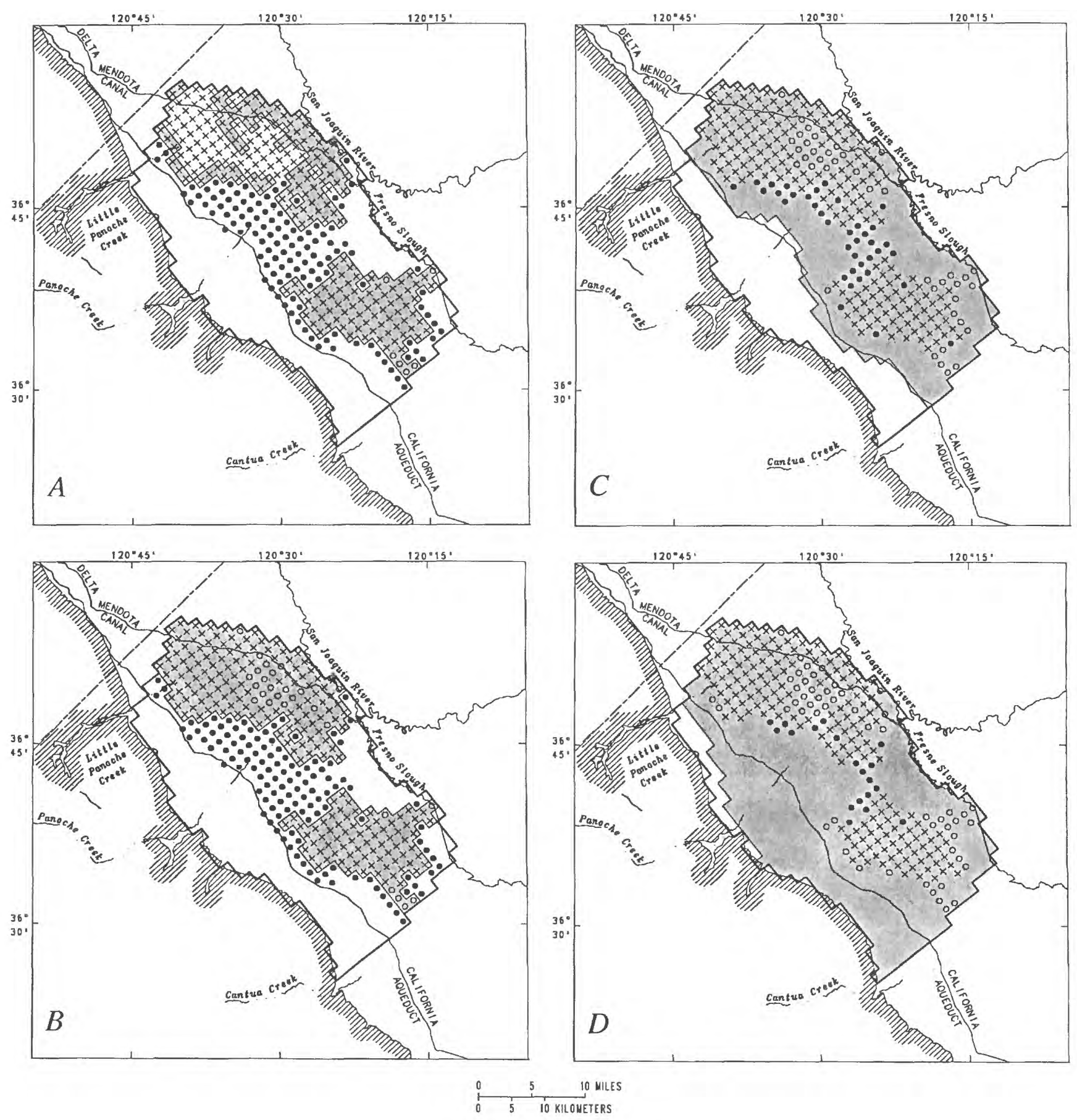

EXPLANATION

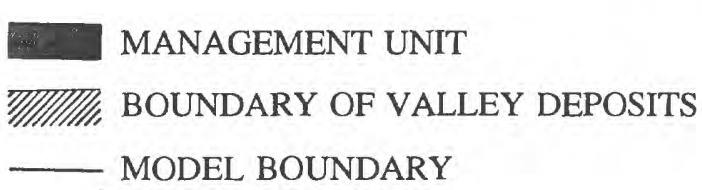
CELLS SUBJECT TO BARE-SOIL EVAPORATION BY 2040
$\times \quad$ Existing in 1990
- $\quad$ Added
- Eliminated

Figure 14. Changes in areal distribution of model cells subject to bare-soil evaporation as a result of reducing recharge to 0.46 foot per year. A, Management unit 1. B, Management unit 2. C. Management unit 3. D, Management unit 4. 
decrease from 1990 to 2000 and will thereafter increase at a relatively modest rate (about 11 cells per decade). Extension of recharge reduction to management unit 4 also results in a decrease in the total number of cells subject to bare-soil evaporation from 1990 to 2000 and a relatively low rate of increase thereafter (about 4 cells per decade).

Figure $13 D$ is a graph of drainflow in the area of on-farm drains for the four scenarios of reduced recharge and for the alternative in which present practices are maintained. Figure $13 D$ indicates a negligible change in drainflow if recharge reduction is limited to management unit 1 and a reduction in drainflow of about $0.3 \mathrm{ft} / \mathrm{yr}$ (about 50 percent) if recharge reduction is extended to management unit 2 . If recharge reduction is extended to management units 3 or 4 , the model indicates an additional decrease in drainflow of about $0.02 \mathrm{ft} / \mathrm{yr}$. These results indicate that drainflow is sensitive to the recharge rate in the area of on-farm drains.

\section{REDUCE RECHARGE BY SPECIFIED PERCENTAGE}

In the previous section, the effects of uniformly reducing recharge to $0.46 \mathrm{ft} / \mathrm{yr}$ were evaluated for various management units. In this section, the effects of reducing recharge by 15,30 , and 45 percent in management unit 4 were evaluated relative to the recharge values calculated for 1980. A reduction of recharge by these percentages would require various degrees of improvement in irrigation efficiency in the various water-budget subareas. Aside from reducing recharge, all other aspects of the model remained the same as the calibrated model.

Figure $15 A$ is a plot of the growth in bare-soil evaporation from 1990 to 2040 . The model indicates that by the year 2040 , the growth in bare-soil evaporation will be 76 cells if recharge is reduced by 15 percent, but can be limited to 32 cells if recharge is reduced by 30 percent, and to 10 cells if recharge is reduced by 45 percent. Figure $15 B$ indicates that during the period of simulation (1990-2040), a 15percent reduction in recharge will have a negligible effect on eliminating cells subject to bare-soil evaporation in 1990 . If, however, recharge is reduced by 30 percent, more than 25 cells can be eliminated, and if recharge is reduced by 45 percent, nearly 120 cells can be eliminated. Figures $15 C$ and 16 indicate that a reduction in recharge of at least 30 percent is necessary in order to hold constant the total number of cells subject to bare-soil evaporation. A 30-percent reduction in recharge would require improvements in irrigation efficiency that may or may not be feasible in some or all water-budget subareas.

Figure $15 D$ indicates that drainflow will be reduced by about $0.12 \mathrm{ft} / \mathrm{yr}$ for each 15 -percent reduction in recharge. In the areas of on-farm drains (Firebaugh, Panoche, and Broadview subareas), a 15percent reduction in recharge corresponds to a decrease in recharge of 0.11 to $0.14 \mathrm{ft} / \mathrm{yr}$. The close correspondence between the amount of decrease in drainflow and amount of decrease in recharge indicates that drainflow is sensitive to recharge in the area of on-farm drains.

\section{GROUND-WATER PUMPING}

\section{CONSTANT PUMPING RATE}

Ground-water pumping, like drains, removes water from the flow system, and is therefore a potentially effective alternative for managing the altitude of a shallow water table. The effectiveness of pumping is limited by two major constraints: withdrawal of poor-quality ground water from the semiconfined zone and aquifer compaction in the confined zone. Ground water pumped from the semiconfined zone, particularly from shallow depths, may be high in selenium and other dissolved constituents and therefore may be unsuitable for irrigation. Consequently, pumping from the deeper parts of the flow system is more desirable from a water-quality perspective, especially from the confined zone. However, ground water pumped from the confined zone may cause a lowering of heads beneath the historically lowest levels (1967) and thus may cause aquifer compaction and land subsidence.

An increase in the current amount of pumping (as calculated from 1980 water-budget data, see table 1) from the existing distribution of wells, as computed by Gronberg and Belitz (1992) (see table 2), is an attractive management alternative because it uses many of the wells already in place, and presumably 

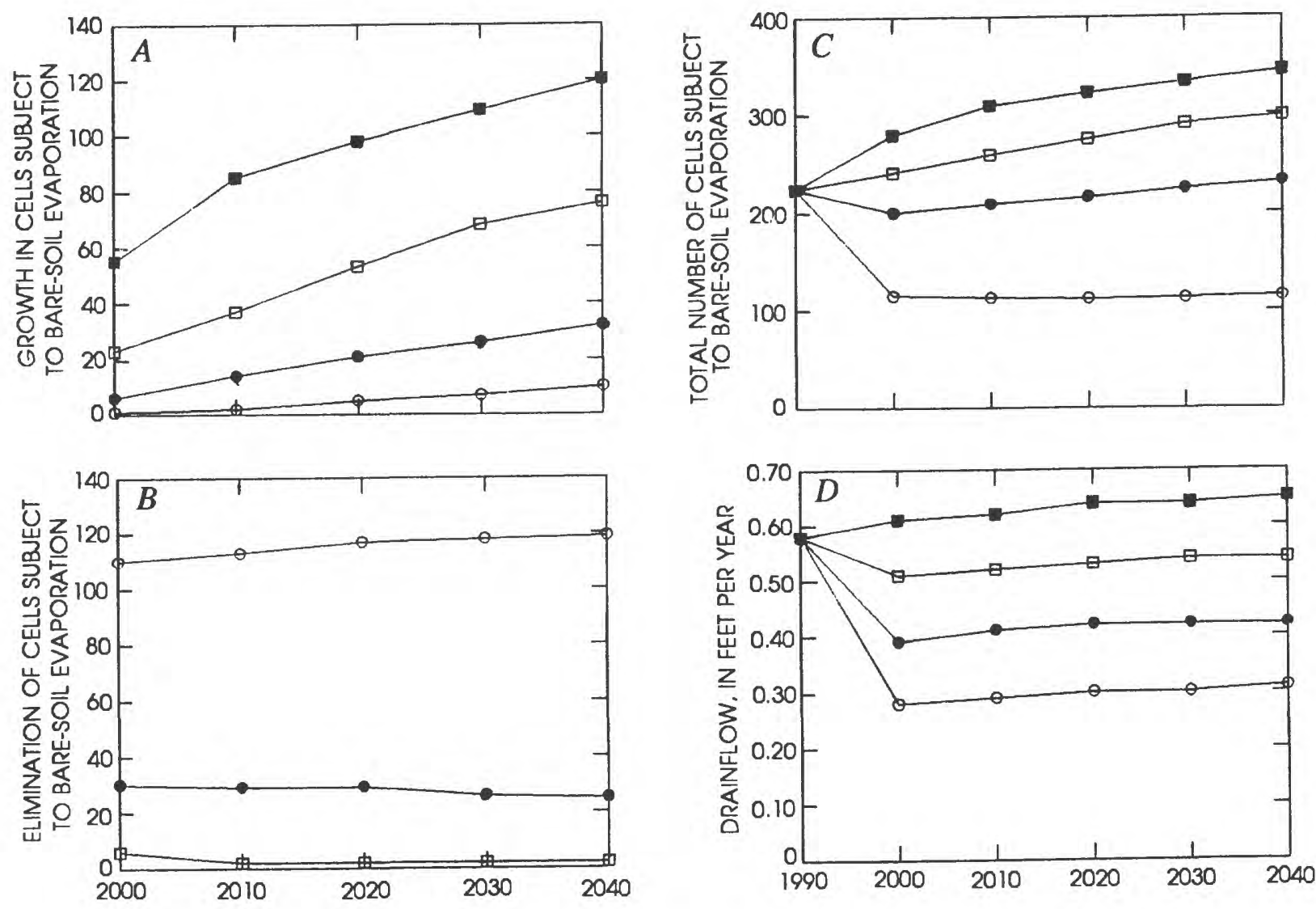

\section{EXPLANATION}

- MAINTAIN PRESENT PRACTICES

REDUCTION OF RECHARGE IN MANAGEMENT UNIT 4

- 15 percent

- 30 percent

- 45 percent

Figure 15. Simulated effects of reducing recharge by 15,30 , and 45 percent in management unit 4 .

those wells are perforated in zones of acceptable water quality. An increase in ground-water pumping from the existing distribution of wells was implemented in management unit 2 (all cells subject to bare-soil evaporation in 1990) and management unit 4 (all cells where the water table is above the
Corcoran Clay Member). Aside from changes in pumping rate, all other aspects of the model remained identical to the calibrated model. Note that an increase in pumping under these conditions necessarily implies an equal reduction in surface-water application. 

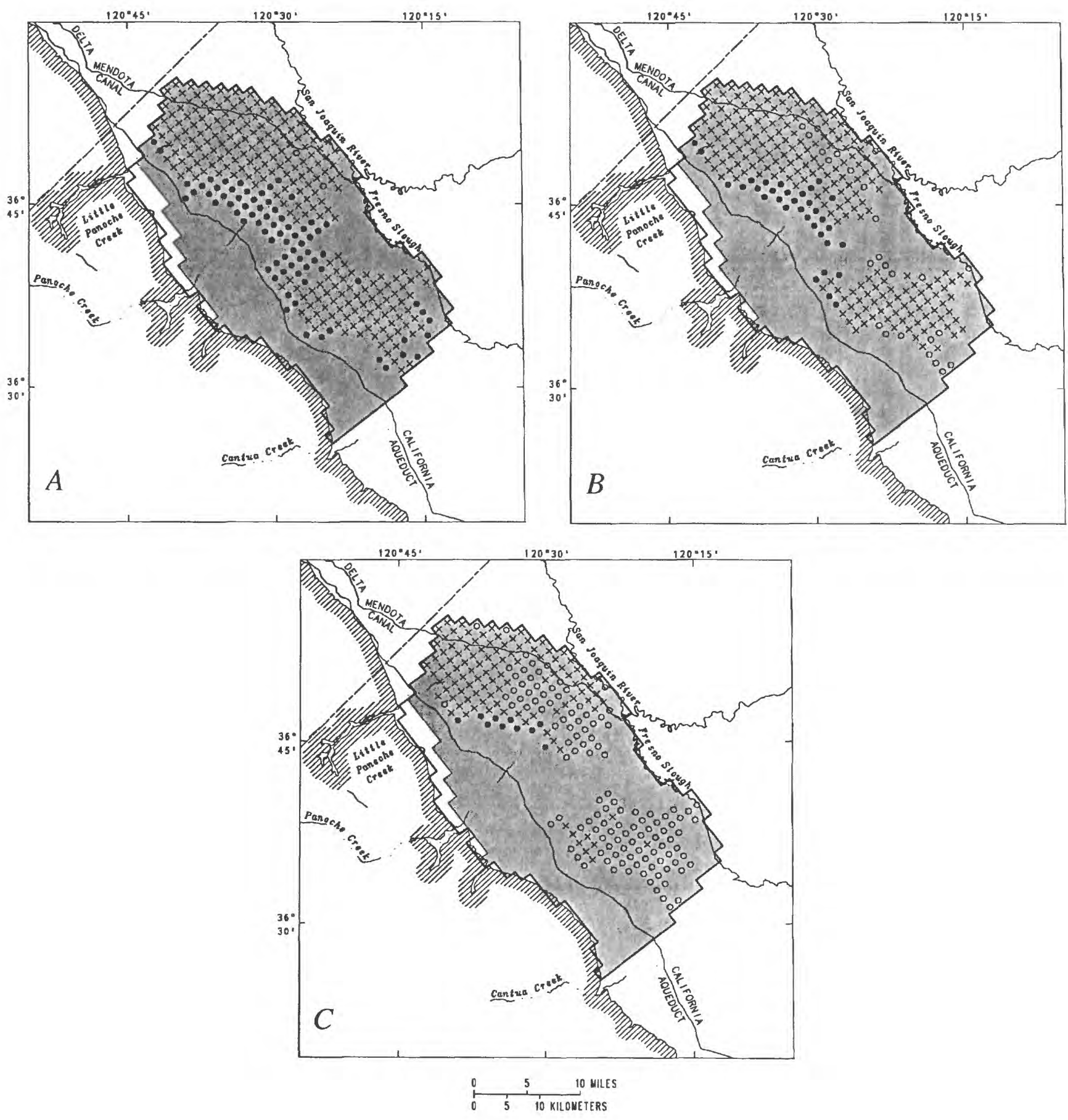

EXPLANATION

MANAGEMENT UNIT

"IIIIIIII, BOUNDARY OF VALLEY DEPOSITS

MODEL BOUNDARY
CELLS SUBJECT TO BARE-SOIL EVAPORATION BY 2040

$\times \quad$ Existing in 1990

- $\quad$ Added

- Eliminated

Figure 16. Changes in areal distribution of model cells subject to bare-soil evaporation as a result of reducing recharge in management unit 4. A, 15 percent. B, 30 percent. C, 45 percent. 
In management units 2 and 4, pumping was incremented systematically by $0.5 \mathrm{ft} / \mathrm{yr}$ in order to find the maximum constant pumping rate that could be supported. The maximum pumping rate was defined as that pumping rate that would not cause a lowering of confined zone heads during the period of simulation (1990-2040) below the 1967 values, the historically lowest heads. The maximum uniform increment in pumping rate (greater than the calculated 1980 values) was $1.0 \mathrm{ft} / \mathrm{yr}$ in management unit 2 and $0.5 \mathrm{ft} / \mathrm{yr}$ in management unit 4 . Total volumes of pumpage for these and other ground-water pumping scenarios are presented in table 3.

Figures 17 and 18 illustrate the effects of uniformly increasing the amount of ground-water pumping from the existing distribution of wells on bare-soil evaporation and drainflow. Figures $17 A$ and $17 B$ indicate that pumping at $1.0 \mathrm{ft} / \mathrm{yr}$ from management unit 2 or at $0.5 \mathrm{ft} / \mathrm{yr}$ from management unit 4 are effective strategies for controlling growth and eliminating bare-soil evaporation. The model indicates that by the year 2040, the growth in cells subject to bare-soil evaporation will be less than 63 cells (120 cells if present practices are maintained) and as many as 50 cells can be eliminated. Figures $17 A$ and
$17 B$ also indicate that pumping at $0.5 \mathrm{ft} / \mathrm{yr}$ from management unit 2 is considerably less effective than the other pumping scenarios. Figure $17 \mathrm{C}$ indicates that the total number of cells subject to bare-soil evaporation can be held to within 20 cells (10 percent) of the total in 1990 . Figure 18 presents the areal distribution of cells subject to bare-soil evaporation for two scenarios of constant increment in pumping: $1.0 \mathrm{ft} / \mathrm{yr}$ from management unit 2 and 0.5 $\mathrm{ft} / \mathrm{yr}$ from management unit 4.

Figure $17 D$ is a graph of drainflow in the area of on-farm drains for the three scenarios in which pumping is increased by a constant increment, and for the alternative in which present practices are maintained. Figure $17 D$ indicates that an increase in pumping rate, or in the size of the area pumped, results in a reduction in drainflow in the area of on-farm drains. Note that an increase in the increment of pumping from 0.5 to $1.0 \mathrm{ft} / \mathrm{yr}$ in management unit 2 is more effective in reducing drainflow than an increase in the size of the area from which an increment of $0.5 \mathrm{ft} / \mathrm{yr}$ is pumped. Figure $17 \mathrm{D}$ also indicates an incremental decrease in drainflow of about $0.1 \mathrm{ft} / \mathrm{yr}$ for each incremental increase in pumping of $0.5 \mathrm{ft} / \mathrm{yr}$.

Table 3. Number of model cells with increments in pumping at specified rates and total incremental volume of pumpage for various pumping management scenarios

[ft/yr, foot per year; acre-ft/yr, acre-foot per year; --, no data]

\begin{tabular}{|c|c|c|c|c|c|}
\hline \multirow[t]{2}{*}{ Management scenario } & \multicolumn{4}{|c|}{$\begin{array}{l}\text { Number of cells with increment in } \\
\text { pumping at specified rate }(\mathrm{ft} / \mathrm{yr})\end{array}$} & \multirow{2}{*}{$\begin{array}{l}\text { Total incremental vol- } \\
\text { ume of pumpage } \\
\text { (thousands of } \\
\text { acre-ft/yr) }\end{array}$} \\
\hline & 0.0 & 0.5 & 1.0 & 1.5 & \\
\hline \multicolumn{6}{|l|}{ Constant pumping increment } \\
\hline \multicolumn{6}{|l|}{ Increase pumping from semiconfined and confined zones } \\
\hline Management unit $2 \ldots \ldots \ldots \ldots \ldots$ & -- & -- & 224 & -- & 143 \\
\hline Management unit $4 \ldots \ldots \ldots \ldots \ldots \ldots$ & -- & 530 & -- & -- & 170 \\
\hline \multicolumn{6}{|l|}{ Variable pumping increment } \\
\hline \multicolumn{6}{|l|}{ Increase pumping from semiconfined and confined zones } \\
\hline Management unit $2 \ldots \ldots \ldots \ldots \ldots \ldots \ldots$ & 7 & 15 & 29 & 173 & 189 \\
\hline Management unit $4 \ldots \ldots \ldots \ldots \ldots \ldots$ & 122 & 172 & 236 & 0 & 206 \\
\hline \multicolumn{6}{|l|}{ Increase pumping from confined zone } \\
\hline Management unit $2 \ldots \ldots \ldots \ldots \ldots \ldots \ldots$ & 18 & 70 & 136 & 0 & 109 \\
\hline Management unit $4 \ldots \ldots \ldots \ldots \ldots \ldots \ldots \ldots$ & 95 & 435 & 0 & 0 & 139 \\
\hline
\end{tabular}



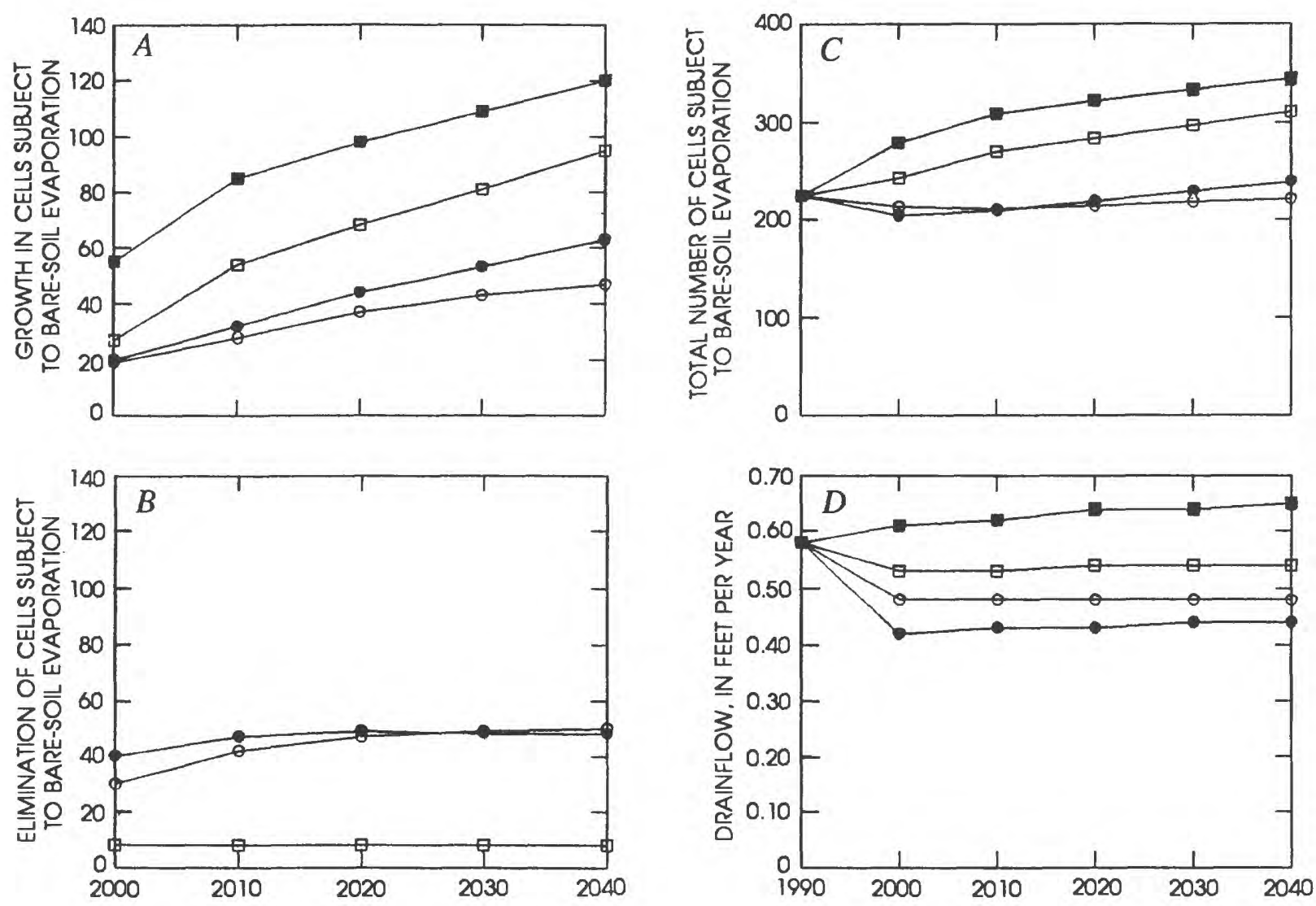

\section{EXPLANATION}

- MAINTAIN PRESENT PRACTICES

INCREASE IN PUMPING BY A CONSTANT INCREMENT

IN MANAGEMENT UNITS

- Unit 2, 0.5 foot per year

- Unit 2, 1.0 foot per year

- Unit 4, 0.5 foot per year

Figure 17. Simulated effects of increasing pumping by a constant increment from existing wells in management units 2 and 4. 


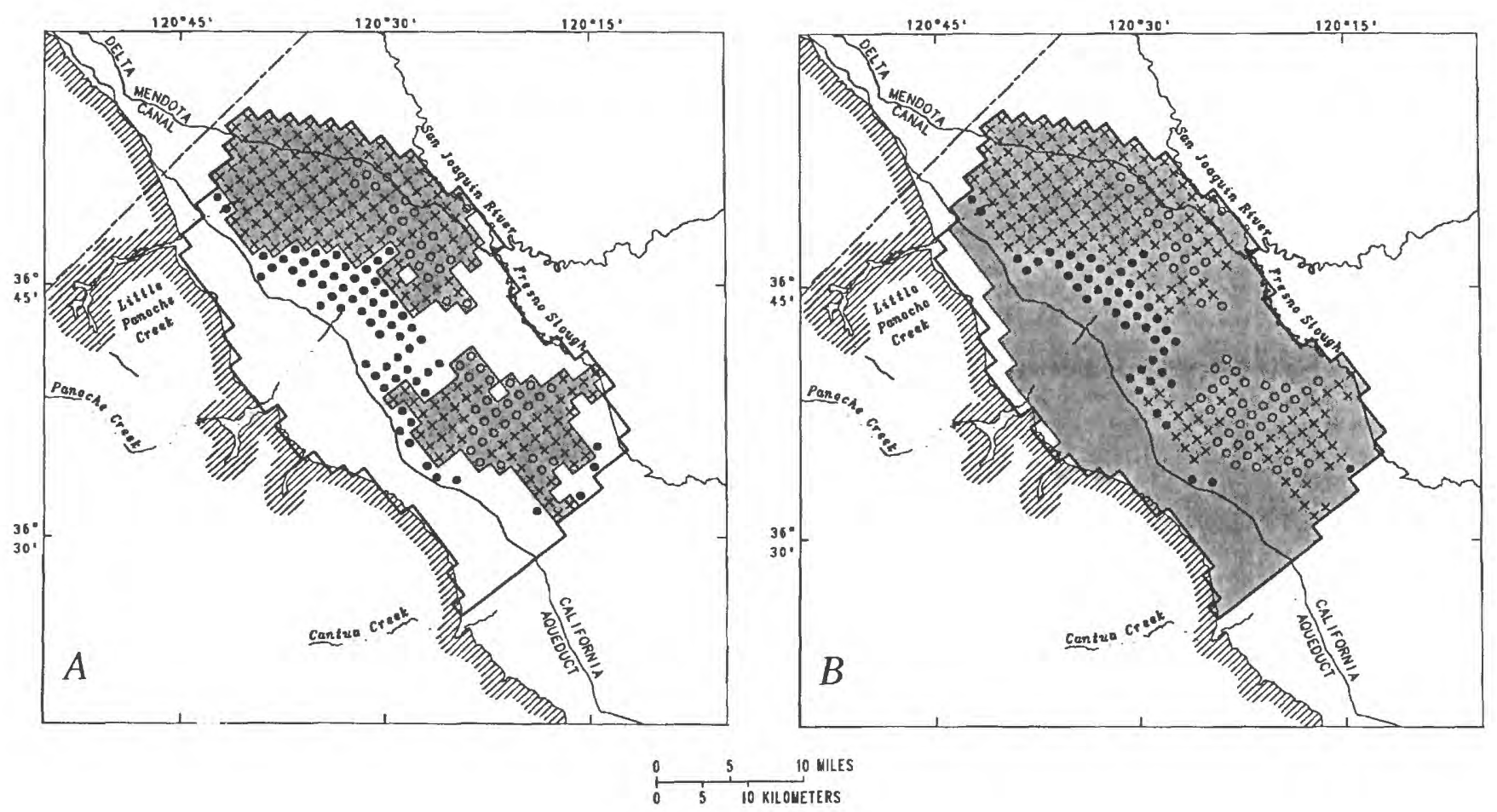

EXPLANATION

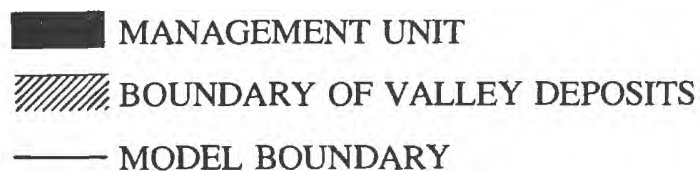

CELLS SUBJECT TO BARE-SOIL
EVAPORATION BY 2040
$\times \quad$ Existing in 1990
-
Added
Eliminated

Figure 18. Changes in areal distribution of model cells subject to bare-soil evaporation by the year 2040 when simulating an increase in pumping by a constant increment from existing wells. A, Management unit 2, 1.0 foot per year constant pumping increment. B, Management unit $4,0.5$ foot per year constant pumping increment.

\section{VARIABLE PUMPING RATE}

The effects of pumping from the existing distribution of wells on bare-soil evaporation might be increased by selectively increasing the pumping rate rather than using a constant increment. Two scenarios for selective increases in pumping were identified: (1) an increment in pumping ranging from 0 to $1.5 \mathrm{ft} / \mathrm{yr}$ in management unit 2 ; and (2) an increment in pumping ranging from 0 to $1.0 \mathrm{ft} / \mathrm{yr}$ in management unit 4 . For both scenarios, pumping was increased in all cells in the management unit by the maximum rate, and the simulated confined zone heads were compared to the measured 1967 values. If a simulated head value was lower than the measured
1967 value, the pumping rate was decreased by 0.5 $\mathrm{ft} / \mathrm{yr}$ in that cell; if the simulated head value continued to be low, the procedure was repeated. Table 3 summarizes the pumping distribution which results from this procedure.

Comparison of figures 17 and 19 provides perspective on the benefits of variable increments in pumping relative to constant increments in pumping. Comparison of figures $17 A$ and $19 A$ indicates that a variable increment in pumping is more effective than a constant increment for controlling the growth in cells subject to bare-soil evaporation. For example, the model indicates that by the year 2040 , a variable increment in pumping from management unit 4 will 

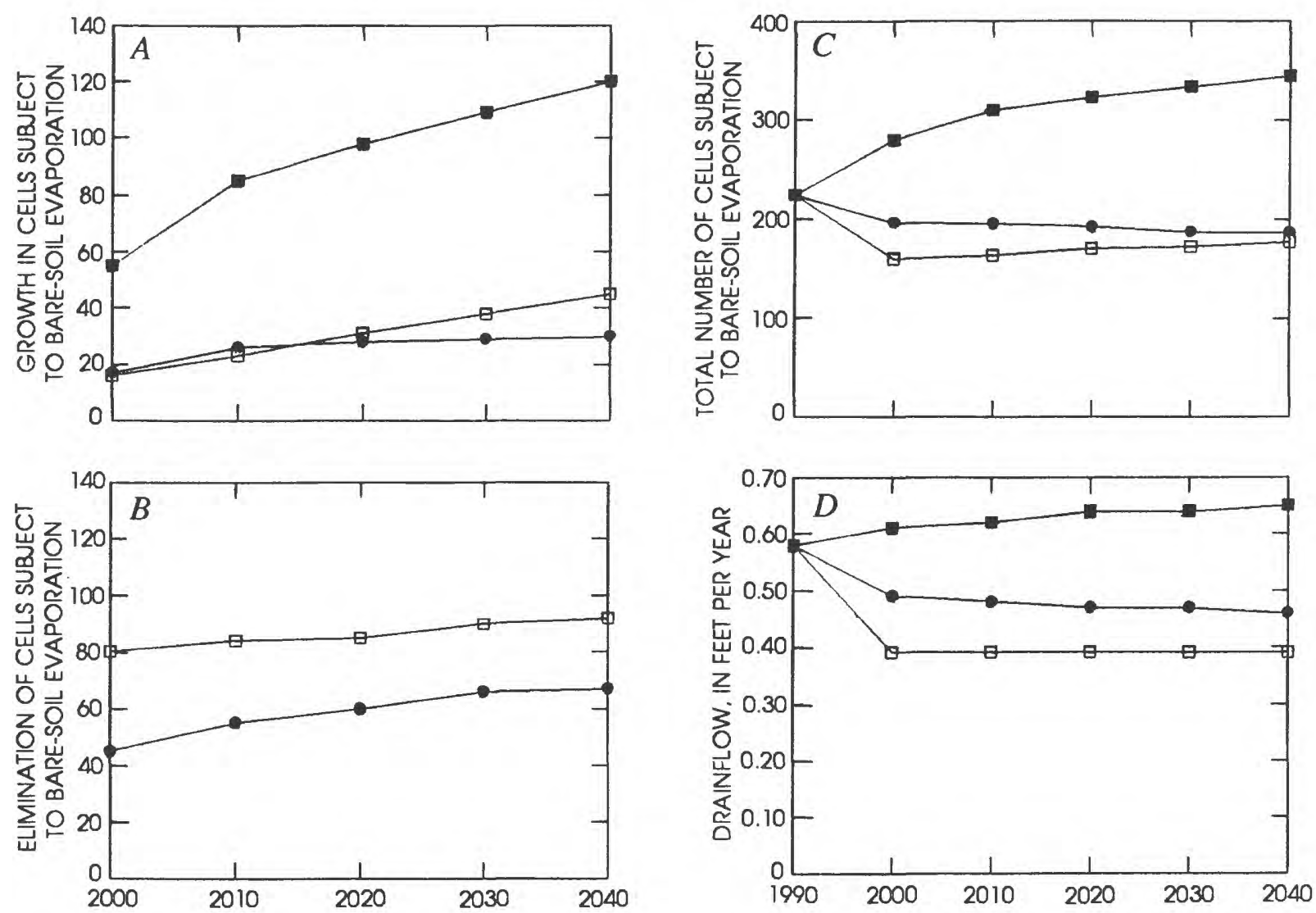

\section{EXPLANATION}

- MAINTAIN PRESENT PRACTICES

INCREASE IN PUMPING BY A VARIABLE INCREMENT IN MANAGEMENT UNITS

- Unit 2, 1.5 feet per year

- Unit 4, 1.0 foot per year

Figure 19. Simulated effects of increasing pumping by a variable increment from existing wells in management units 2 and 4.

result in 30 additional cells subject to bare-soil evaporation, as compared to 47 additional cells if the increment is constant. Comparison of figures $17 B$ and $19 B$ indicates that a variable increment in pumping results in a substantial improvement in the elimination of cells subject to bare-soil evaporation. For example, the model indicates that by 2040 , an incremental increase in pumping from management 
unit 2 will result in elimination of 92 cells, as compared to 48 cells eliminated if the increment is constant. Figure $19 C$, which shows the total number of cells subject to bare-soil evaporation, illustrates the effects of variable increments in pumping on controlling the altitude of the water table. Comparison of figures $17 D$ and $19 D$ indicates that drainflow is unaffected by a change from constant-increment pumping to variable-increment pumping in either management units 2 or 4 . Figure 20 shows the areal distribution of variable pumping increments from existing wells in management units 2 and 4 . The effect on the distribution of model cells subject to bare-soil evaporation by the year 2040 is shown in figure 21 .

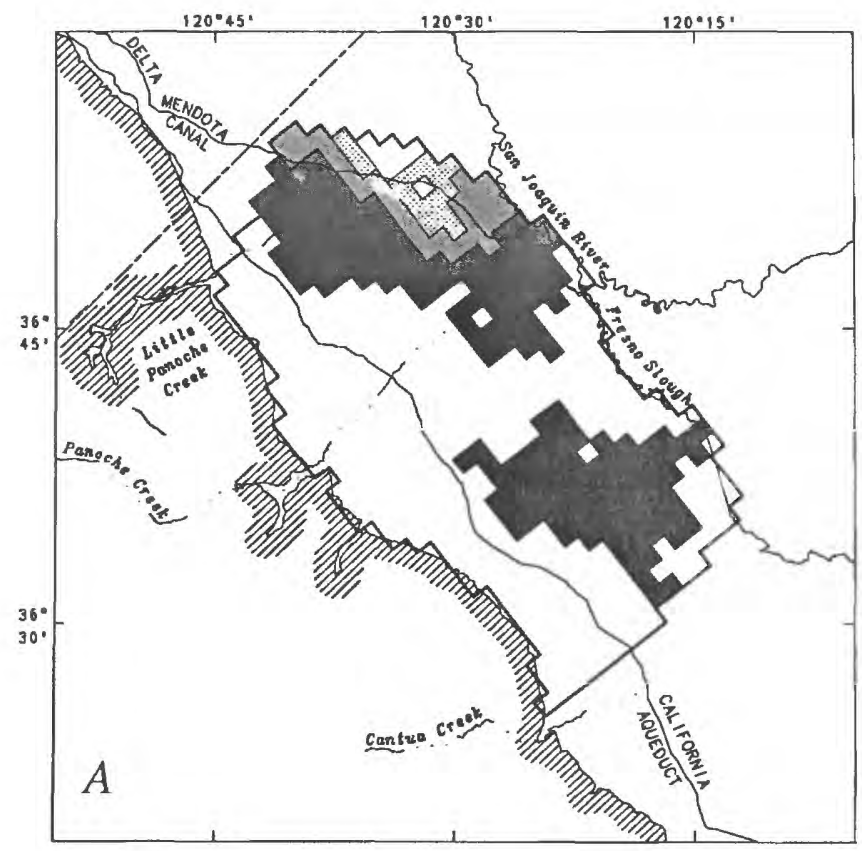

\section{INCREASED PUMPING FROM THE CONFINED ZONE ONLY}

The occurrence of selenium and other dissolved constituents in the semiconfined zone is a potential limitation on ground-water pumping. Consequently, it has been proposed that pumping be limited to the confined zone only (San Joaquin Valley Drainage Program, 1989a). The effects of increasing pumping from the confined zone only was evaluated in management units 2 and 4 . Initially, pumping was increased (relative to the calculated 1980 values) in increments of $0.5 \mathrm{ft} / \mathrm{yr}$ in order to find the maximum increment in pumping rate that could be sustained. A uniform increment of $0.5 \mathrm{ft} / \mathrm{yr}$ can be sustained in

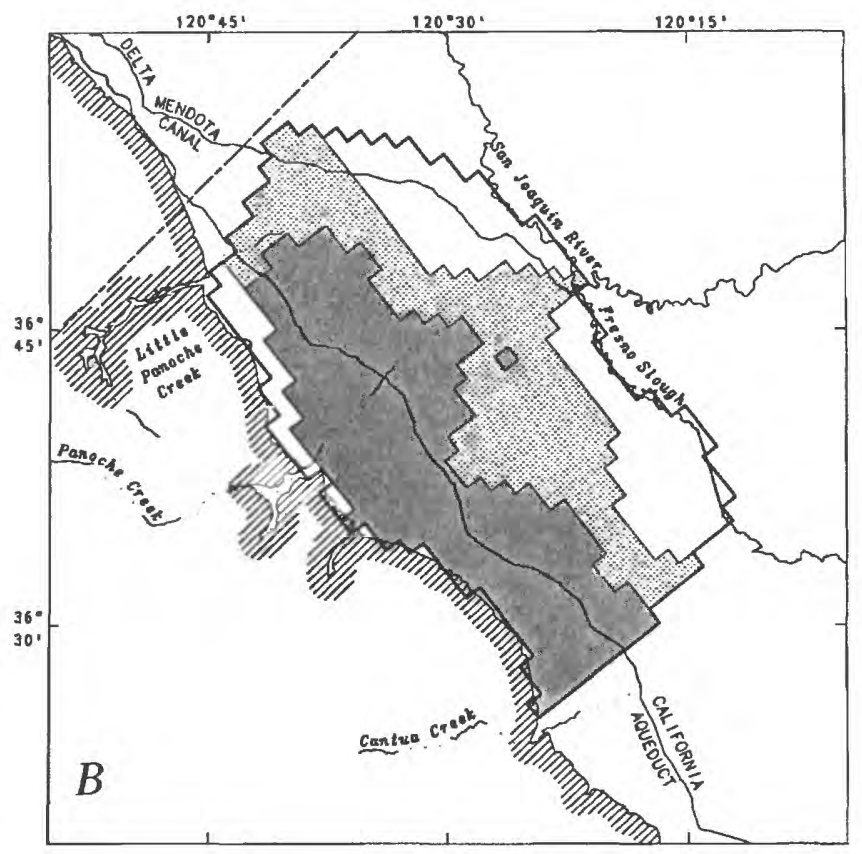

10 MILES

NILUETERS

EXPLANATION

VARIABLE PUMPING INCREMENTS, IN FEET PER YEAR

"TITIII/, BOUNDARY OF VALLEY DEPOSITS - MODEL BOUNDARY

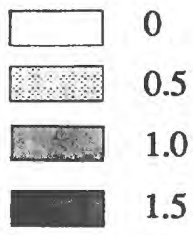

Figure 20. Areal distribution of variable pumping increments from existing wells in management units 2 (A) and $4(B)$. 

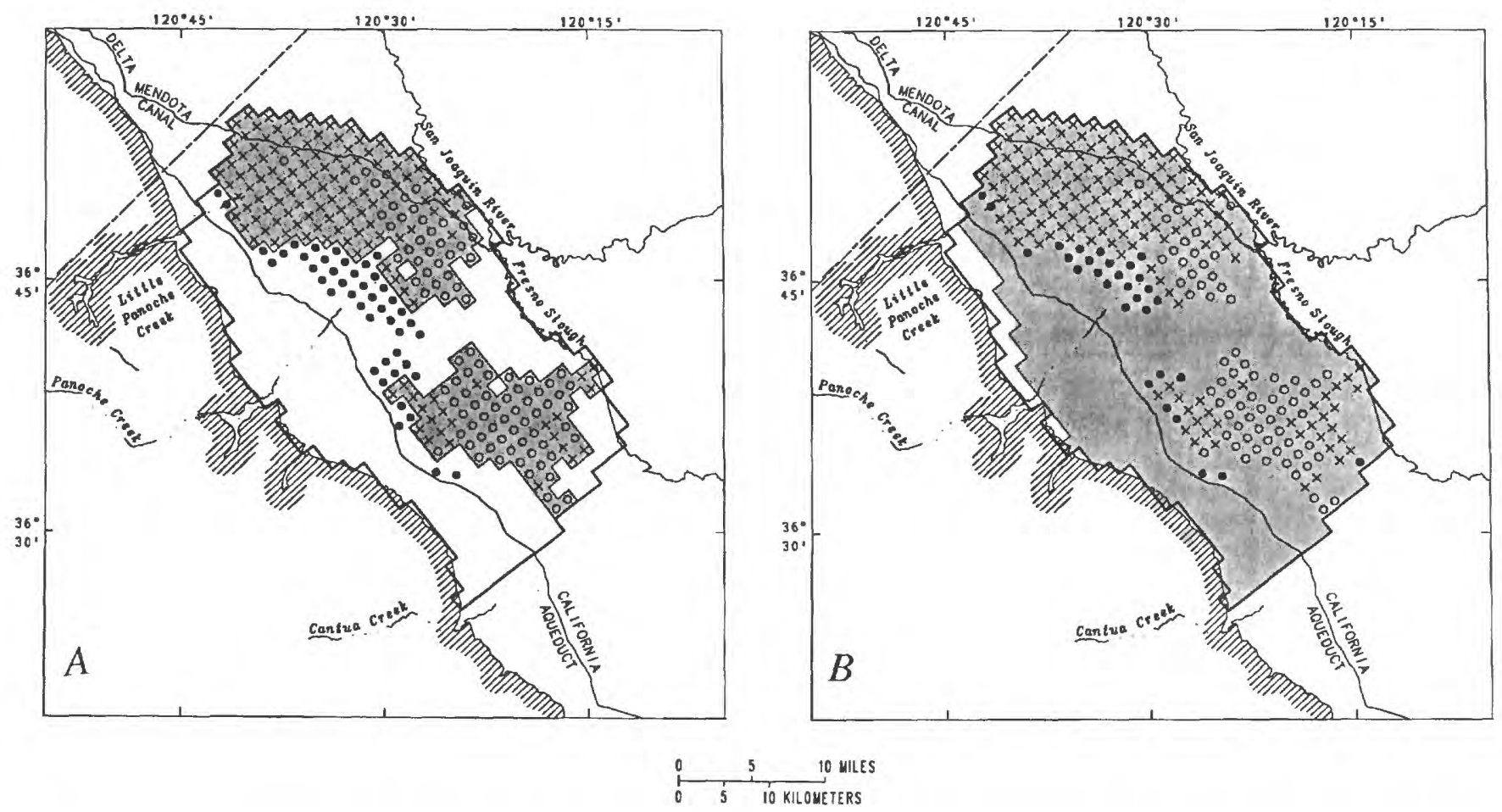

\section{EXPLANATION}

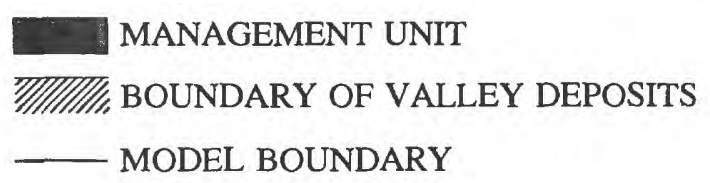

\author{
CELLS SUBJECT TO BARE-SOIL \\ EVAPORATION BY 2040 \\ $\times \quad$ Existing in 1990 \\ - $\quad$ Added \\ - Eliminated
}

Figure 21. Changes in areal distribution of model cells subject to bare-soil evaporation by the year 2040 when simulating an increase in pumping by a variable increment from existing wells. A, Management unit 2. B, Management unit 4 .

management unit 2 but cannot be sustained in management unit 4. Subsequently, pumping was incremented selectively by as much as $1.0 \mathrm{ft} / \mathrm{yr}$ in management unit 2 , and as much as $0.5 \mathrm{ft} / \mathrm{yr}$ in management unit 4. Table 3 summarizes the number of cells with additional pumping at the variable increments.

Comparison of figures 17 and 22 provides perspective on the loss in effectiveness which results from restricting an increase in pumping to the confined zone only (fig. 17 summarizes the results of a uniform increment in pumping). An increase in pumping from the confined zone only has a similar effect on the growth in bare-soil evaporation as an increase from the semiconfined and confined zones (figs. 17A and 22A). For example, the model indicates that by 2040 , an additional 55 cells will be subject to bare-soil evaporation if additional pumping from management unit 4 is limited to the confined zone only, as compared to 47 additional cells if pumping is increased in the confined and semiconfined zones. This result can be understood by comparing the location of the additional cells subject to evaporation (figs. 18 or 21 ) with the existing distribution of pumping (fig. 4 and table 2). The areas of growth occur primarily in the Westlands Water District where the Sierran sand is absent. In that area, 6 percent of the pumping is from the semiconfined zone and 94 percent is from the confined zone (table 2); therefore, a restriction of pumping to the confined zone results in a minimal loss of effectiveness. 

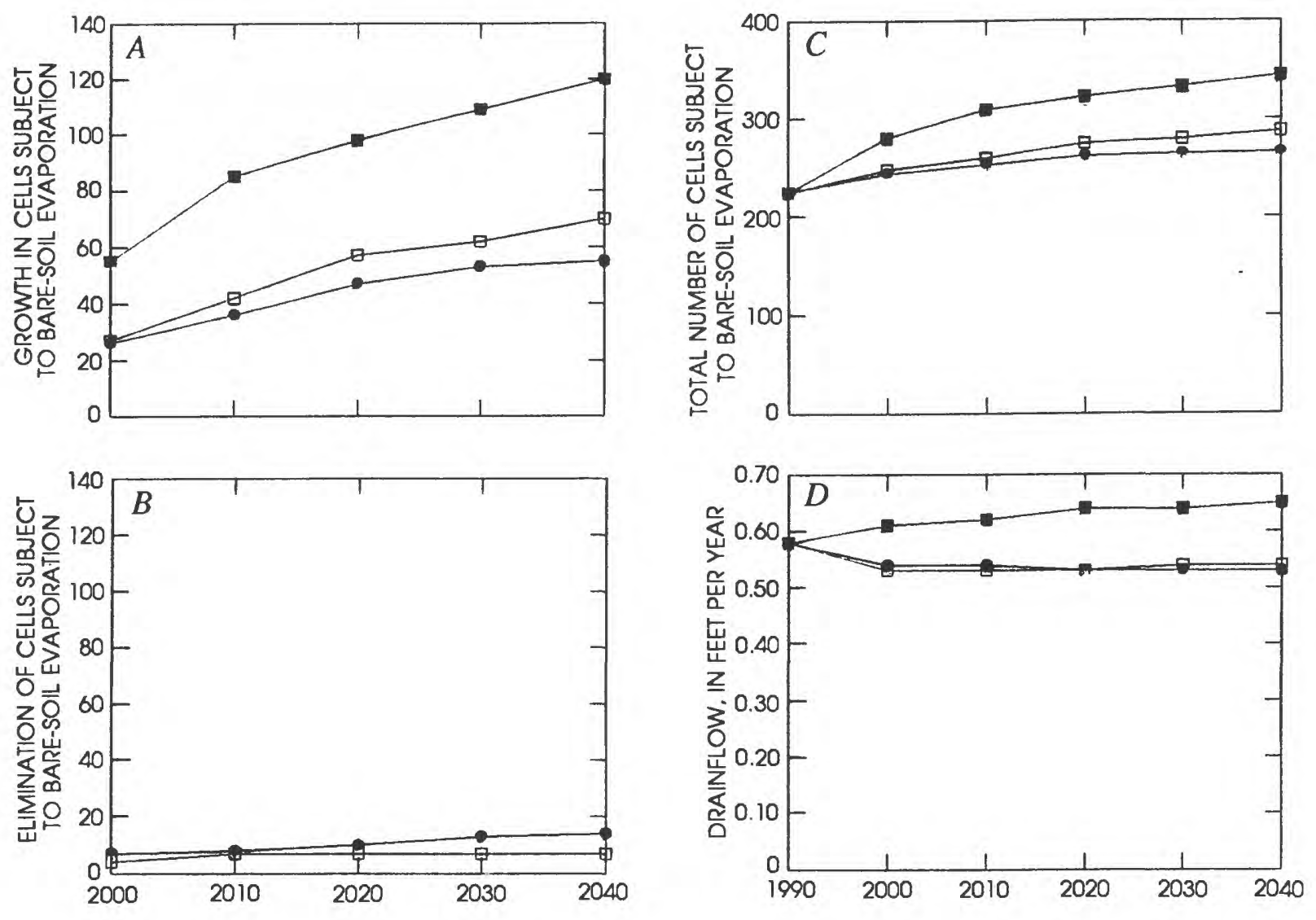

\section{EXPLANATION}

- MAINTAIN PRESENT PRACTICES

INCREASE IN PUMPING BY A VARIABLE INCREMENT FROM THE CONFINED ZONE ONLY IN MANAGEMENT UNITS

- Unit 2, 1.0 foot per year

- Unit 4, 0.5 foot per year

Figure 22. Simulated effects of increasing pumping by a variable increment from the confined zone only in management units 2 and 4.

The model indicates that a restriction of additional pumping to the confined zone reduces the ability of pumping to eliminate bare-soil evaporation (compare figs. $17 \mathrm{~B}$ and $22 \mathrm{~B}$ ). The model indicates that by 2040,14 cells will be eliminated if additional pumping in management unit 4 is limited to the confined zone only, as compared to 50 cells eliminated if additional pumping is from the semiconfined and confined zones. This result can be understood by comparing the location of cells eliminated (fig. 18) with the existing distribution of pumping (fig. 4 and table 2). The areas eliminated are primarily in the 
Westlands Water District where the Sierran sand is present (north and south) and in the Firebaugh subarea where the Sierran sand is also present. In these areas, pumping from the semiconfined zone ranges from 35 to 95 percent; therefore, a restriction of pumping to the confined zone only has a significant detrimental effect with respect to elimination of baresoil evaporation.

The model also indicates that if the increment in pumping is restricted to the confined zone only, the total number of cells subject to bare-soil evaporation and the drainflow rate will be about half-way between maintaining present practices and uniformly increasing pumping from the semiconfined and confined zones (compare figs. $17 C$ and $22 C$, and figs. $17 D$ and $22 D$ ). Figure 23 shows the areal distribution of variable pumping increments from the confined zone only in management units 2 and 4 . The effect on the distribution of cells subject to bare-soil evaporation by the year 2040 is shown in figure 24.

\section{REDUCE RECHARGE AND INCREASE GROUND- WATER PUMPING}

In the previous sections, the sensitivity of the water table to various individual management alternatives was evaluated. In this section, the effects of combining recharge reduction with increased groundwater pumping are evaluated. The amount of recharge reduction and increased pumping was based on an analysis of the water-budget data presented in table 1 and on the results of the previous sections.
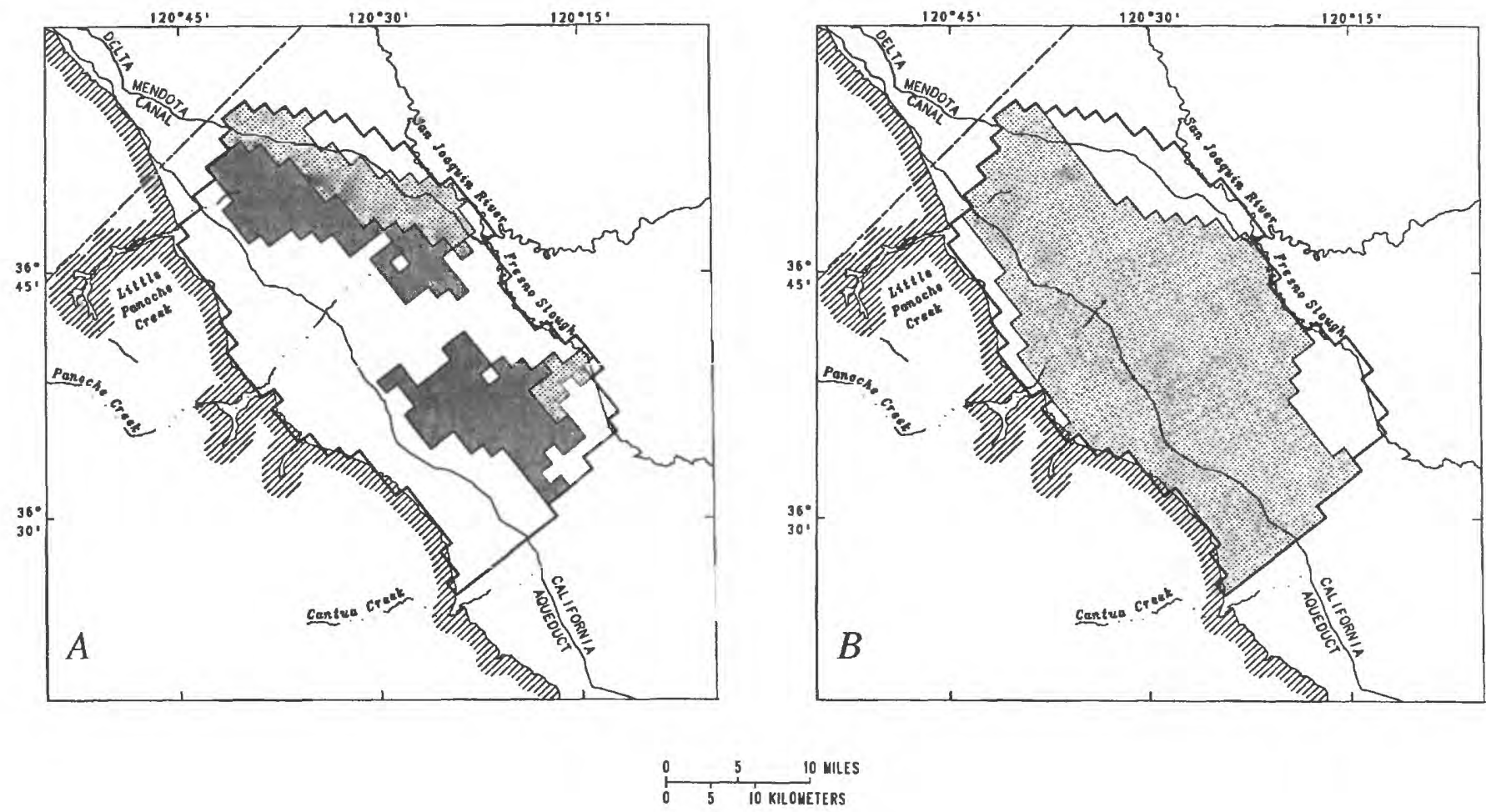

\section{EXPLANATION}

VARIABLE PUMPING INCREMENTS, IN FEET PER YEAR

MIIIII/. BOUNDARY OF VALLEY DEPOSITS

0

MODEL BOUNDARY

0.5

1.0

Figure 23. Areal distribution of variable pumping increments from the confined zone only in management units $2(A)$ and $4(B)$. 


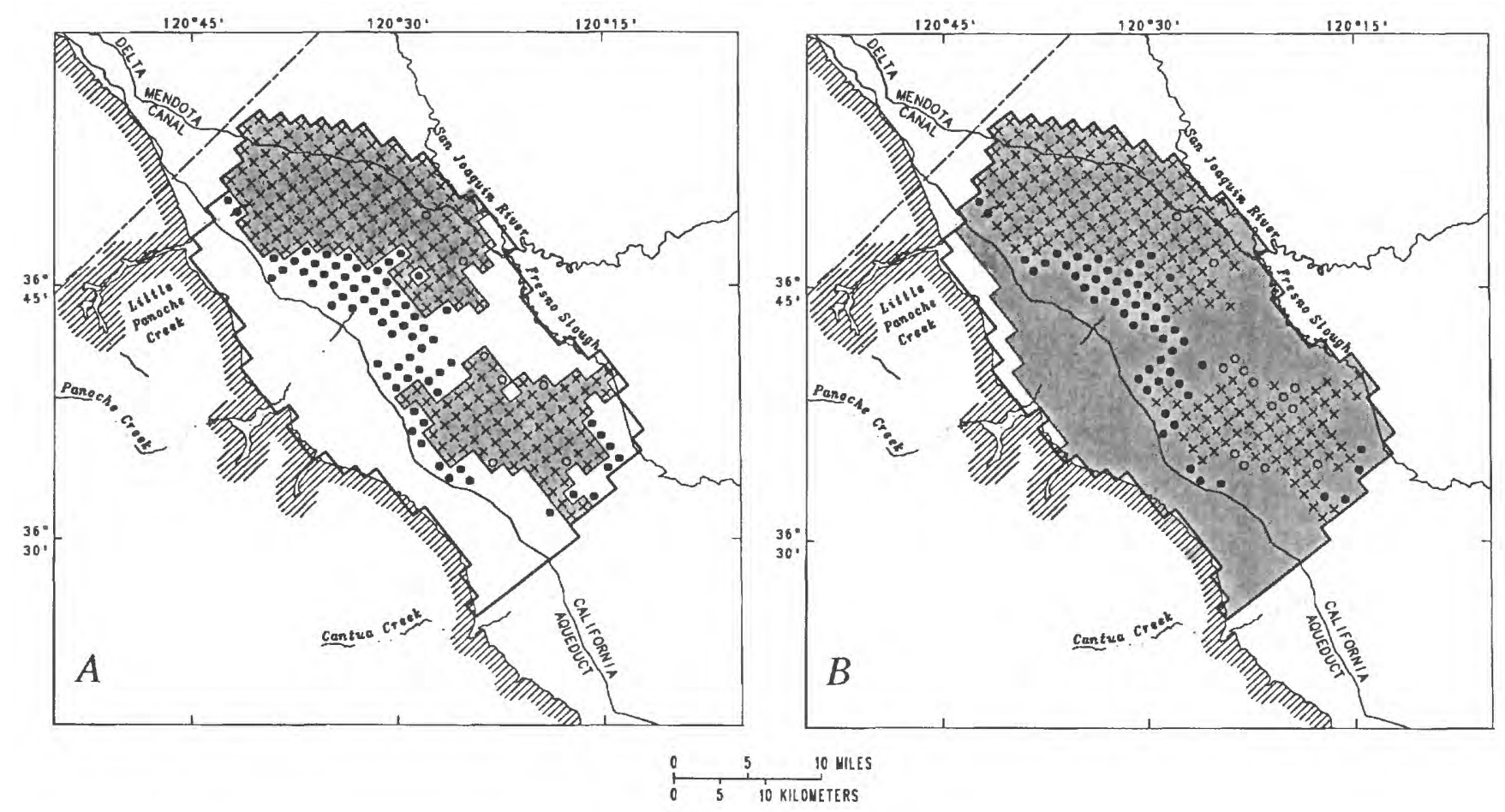

EXPLANATION

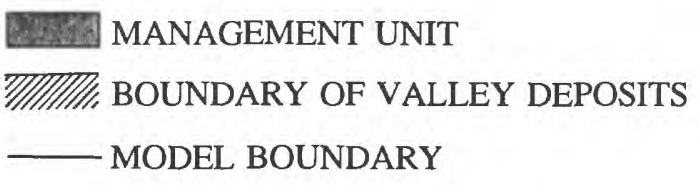

\author{
CELLS SUBJECT TO BARE-SOIL \\ EVAPORATION BY 2040 \\ $\times \quad$ Existing in 1990 \\ - $\quad$ Added \\ - Eliminated
}

Figure 24. Changes in areal distribution of model cells subject to bare-soil evaporation by the year 2040 when simulating an increase in pumping by a variable increment from the confined zone only. A, Management unit 2. B, Management unit 4.

The water-budget data (table 1) presented by Gronberg and Belitz (1992) indicates that in five of the nine subareas, surface-water delivery is insufficient to meet the calculated irrigation requirement; therefore, ground-water pumping is needed as a supplement in these subareas. Surface-water delivery exceeds the calculated irrigation requirement in three of the subareas; therefore, there is no need for ground-water pumping in these subareas. One subarea relies entirely on ground water as there is no surface-water delivery. The three subareas with a calculated excess of surface water are serviced by on-farm drains, and the six subareas with a calculated need for ground-water pumping are not serviced by on-farm drains.
Two scenarios were used to evaluate the response of the water table to changes in the rates of recharge and pumping (note: the modifications were made relative to the 1980 values, table 1 ). In the first scenario, recharge in the Firebaugh, Panoche, and Broadview subareas was decreased by an amount equal to the difference between surface-water delivery and calculated irrigation requirement. For the five subareas that require ground-water pumping as a supplement to surface water, pumping was increased by $0.5 \mathrm{ft} / \mathrm{yr}$ from the semiconfined and confined zones, and recharge was reduced by 15 percent. In the subarea without surface-water delivery, recharge and pumping were held constant. In the second scenario, the rates of recharge were decreased as in the first 
scenario, and pumping was increased by $0.5 \mathrm{ft} / \mathrm{yr}$ from the confined zone in four of the five subareas (San Luis and the three Westlands subareas with surface-water delivery). To avoid lowering the confined zone heads below the measured 1967 values, pumping was not incremented in the confined zone in the Tranquillity subarea. In the subarea without surface-water delivery, recharge and pumping also were held constant as in the first scenario.
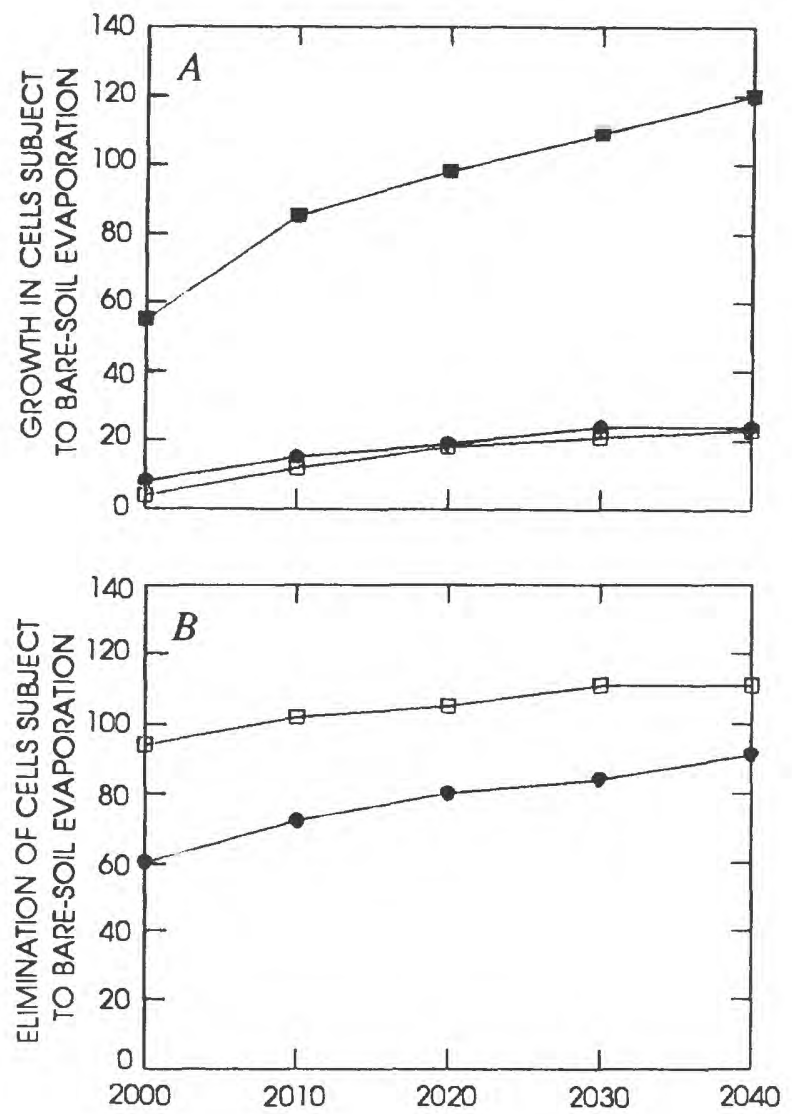

Figures 25 and 26 illustrate the effects of implementing a program of reduced recharge and increased pumping. Figure $25 \mathrm{~A}$ indicates that the growth in cells subject to bare-soil evaporation can be held to less than 25 cells, as compared to 120 cells if present practices are maintained. Figure $25 B$ indicates that 111 of the 224 cells subject to bare-soil evaporation in 1990 can be eliminated by 2040 . Figures $25 C$ and 26 illustrate the effect that a program of reduced
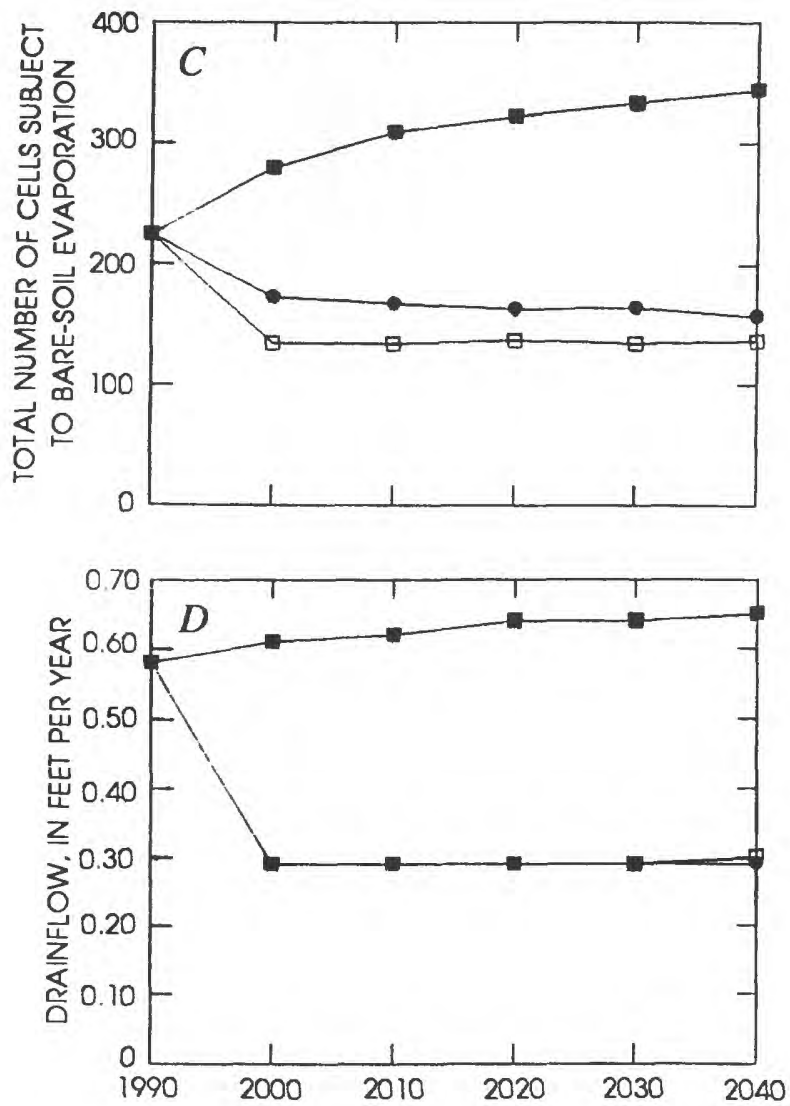

\section{EXPLANATION}

- MAINTAIN PRESENT PRACTICES

- REDUCE RECHARGE AND INCREASE PUMPING FROM EXISTING WELLS

- REDUCE RECHARGE AND INCREASE PUMPING FROM CONFINED ZONE ONLY

Figure 25. Simulated effects of the combination of reducing recharge and increasing pumping from existing wells or from the confined zone only. 


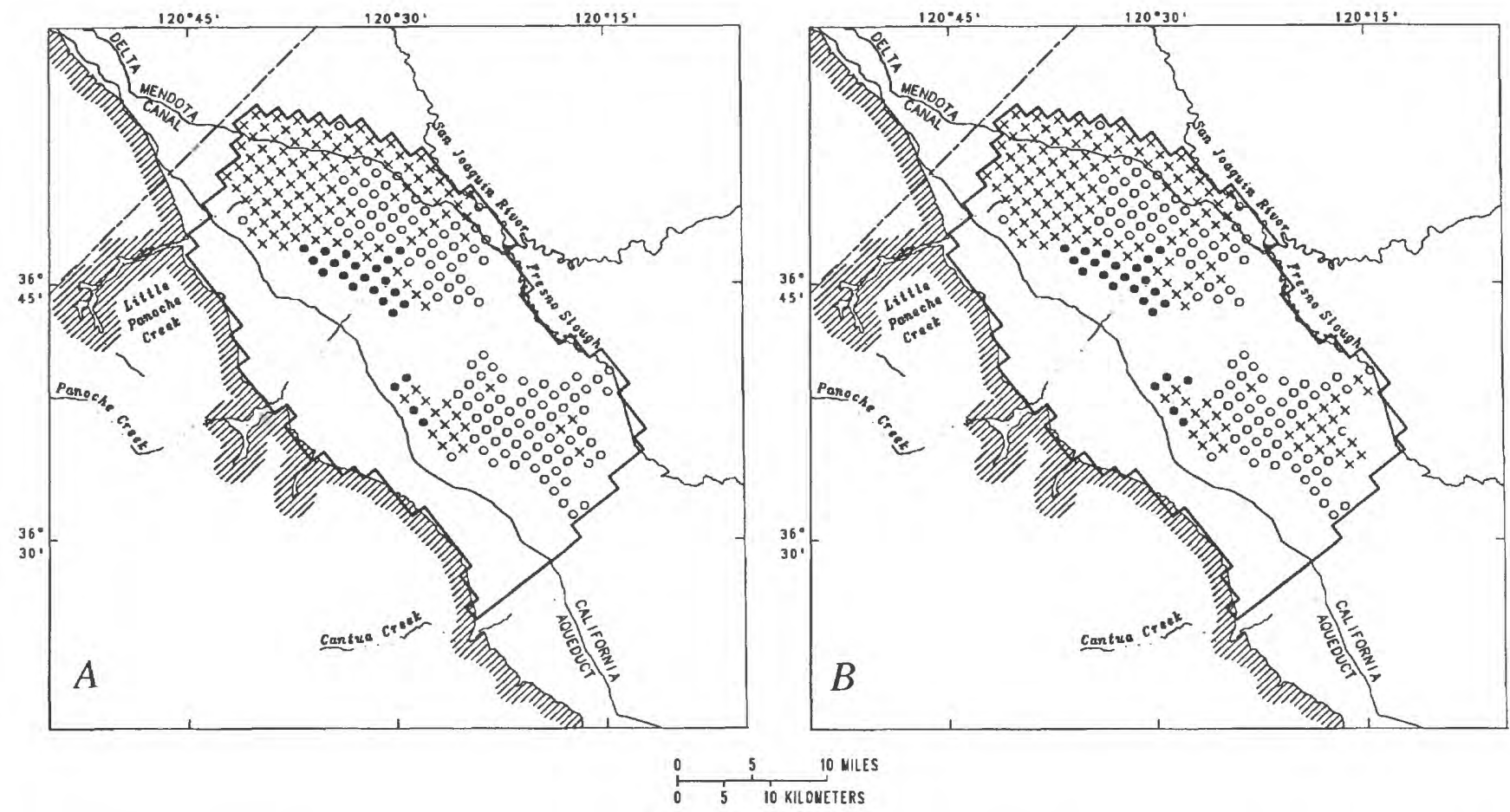

EXPLANATION

TIIIIII/, BOUNDARY OF VALLEY DEPOSITS MODEL BOUNDARY
CELLS SUBJECT TO BARE-SOIL EVAPORATION BY 2040

$\begin{array}{ll}\times & \text { Existing in } 1990 \\ \text { - } & \text { Added } \\ \text { - Eliminated }\end{array}$

Figure 26. Changes in areal distribution of model cells subject to bare-soil evaporation by the year 2040 when simulating the combined effects of reducing recharge and increasing pumping from $(A)$ existing wells or from $(B)$ the confined zone only.

recharge and increased pumping has on the number of cells subject to bare-soil evaporation. Figure $25 D$ indicates that drainflow is reduced to $0.30 \mathrm{ft} / \mathrm{yr}$ in 2040 , as compared to $0.65 \mathrm{ft} / \mathrm{yr}$ if present practices are maintained.

An increase in pumping from below the Corcoran Clay Member only is nearly as effective as an increase in pumping from above and below the Corcoran Clay Member in controlling the number of cells subject to bare-soil evaporation and in reducing drainflow. This result can be partly understood by examining the growth in cells subject to evaporation, the elimination of cells subject to evaporation, and drainflow. The growth in cells subject to evaporation occurs primarily in areas where the existing distribution of pumping (fig. 4, table 2) is 6 percent from the semiconfined zone and 94 percent from the confined zone; therefore, a restriction of pumping to the confined zone has little effect. A restriction in pumping to the confined zone, however, does affect the number of cells eliminated. For example, the model indicates that by 2040,91 cells will be eliminated if pumping is restricted to the confined zone, as compared to 111 cells eliminated if pumping is from the semiconfined and confined zones. The difference of 20 cells is comparable in magnitude to the difference of 40 cells indicated previously (see discussion of "ground-water pumping, confined zone only"). The difference of 20 cells, however, is a 
relatively small percentage of the total number eliminated. The reduction in drainflow is primarily a result of the reduction in recharge in the areas of onfarm drains. In the areas of on-farm drains, the average reduction in recharge was about $0.3 \mathrm{ft} / \mathrm{yr}$; the reduction in drainflow ranged from about 0.30 to $0.35 \mathrm{ft} / \mathrm{yr}$.

\section{MANAGEMENT ALTERNATIVES FOR THE}

\section{SAN LUIS UNIT PROPOSED BY THE}

\section{U.S. BUREAU OF RECLAMATION}

The U.S. Bureau of Reclamation (USBR) has evaluated five management alternatives for the San Luis Unit, which includes the Westlands, San Luis, Panoche, Broadview, and Pacheco Water Districts (U.S. Bureau of Reclamation, 1991). The model area in this report includes parts of the Westlands, San Luis, and Panoche Water Districts, all the Broadview Water District, but does not include the Pacheco Water District. For the purposes of analysis, the USBR divided the San Luis Unit into two components: the Westlands Water District and the northern districts. In the model area of this report, the Westlands Water District is represented by 324 cells and the northern districts are represented by 81 cells (a total of $405 \mathrm{mi}^{2}$ ). The model area also includes the Firebaugh and Tranquillity subareas (103 cells), which are not a part of the San Luis Unit.

The USBR defines a baseline of "no action," which is defined as no actions taken by the Federal Government toward solving the drainage problem. Under the no-action alternative, farmers would respond to changing hydrologic conditions by installation of drains, if economically feasible; by land retirement, if the costs of production exceed revenues; and by improvements in irrigation efficiency in response to shallow ground-water conditions and changes in production costs. The no-action alternative also allows for reallocation of conserved water within the Westlands Water District and assumes that the northern districts will continue to discharge drainwater to the San Joaquin River, subject to water-quality regulations, and will recycle drainwater, where possible.

The USBR postulates four alternatives to noaction. Alternative 1 provides for construction of facilities to allow drainage of all lands affected by shallow ground water. Alternative 2 requires management of drainwater and salts within the boundaries of the San Luis Unit and allows for reimbursement of costs associated with improvements in irrigation efficiency, selective transfer of irrigated lands to alternative uses, and for redistribution of conserved water. In the northern districts, alternative 2 also requires cessation of drainwater discharge to the San Joaquin River. Alternative 3 is a combination of alternatives 1 and 2 -- in Westlands, alternative 3 is identical to alternative 2 , and in the northern districts, alternative 3 would restrict the eligibility criteria for transfer of land to alternative uses, would allow for reimbursement of costs associated with improvements in irrigation efficiency, and would provide for construction of drainwater recycling and disposal facilities. Alternative 4 incorporates proposals put forward by the San Joaquin Valley Drainage Program. In the Westlands Water District, alternative 4 would allow for alternative land use and water marketing, and in the northern districts, alternative 4 would allow for alternative land use, water marketing, and construction of drainwater recycling and disposal facilities. Alternative 4 would also provide for monitoring and development of technologies for dealing with drainage problems, including groundwater pumping. The USBR assumes that by 2007 , a technical solution to the drainage problem would have been developed, and thereafter, water marketing and ground-water pumping would be discontinued. A complete discussion of the five management alternatives is provided by U.S. Bureau of Reclamation (1991).

The USBR evaluated the effects of the proposed management alternatives with a simulation model that is driven by on-farm economic decisions (San Joaquin Valley Drainage Program, 1989b; U.S. Bureau of Reclamation, 1991). The model used by the USBR, the Westside Agricultural Drainage Economics (WADE) Model couples an agricultural production model, a hydrologic model, and a salinity model (Hatchett and others, 1991). The WADE model discretizes installation of drains, improvements in irrigation systems, trading of surface water among model cells and to buyers outside the study area, and other decisions that affect recharge to and discharge from the ground-water flow system. Output from the WADE model includes estimates of ground-water recharge (defined by the USBR as deep percolation), drainflow, and ground-water pumping.

The model developed by Belitz and others (1992) was used to help evaluate the hydraulic response of the water table to the stresses predicted by the WADE model. The USGS simulations were configured by specifying recharge and ground-water pumpage on a year-by-year, cell-by-cell basis. For model cells within the San Luis Unit, the recharge rate reflected an adjustment for drainflow and for lands taken out of irrigation as predicted by the WADE model. Drains were not explicitly incorporated in this analysis in order to simplify the installation and closing of drains as a 
function of time. Land retirement and alternative use of land were not explicitly represented in this analysis because they were not explicitly located by the WADE model. The areally distributed rates of recharge as predicted by the WADE model reflect the reduction in total irrigation that results as a consequence of land retirement. The rates of recharge used in the USGS model, however, were lower than the rates predicted by
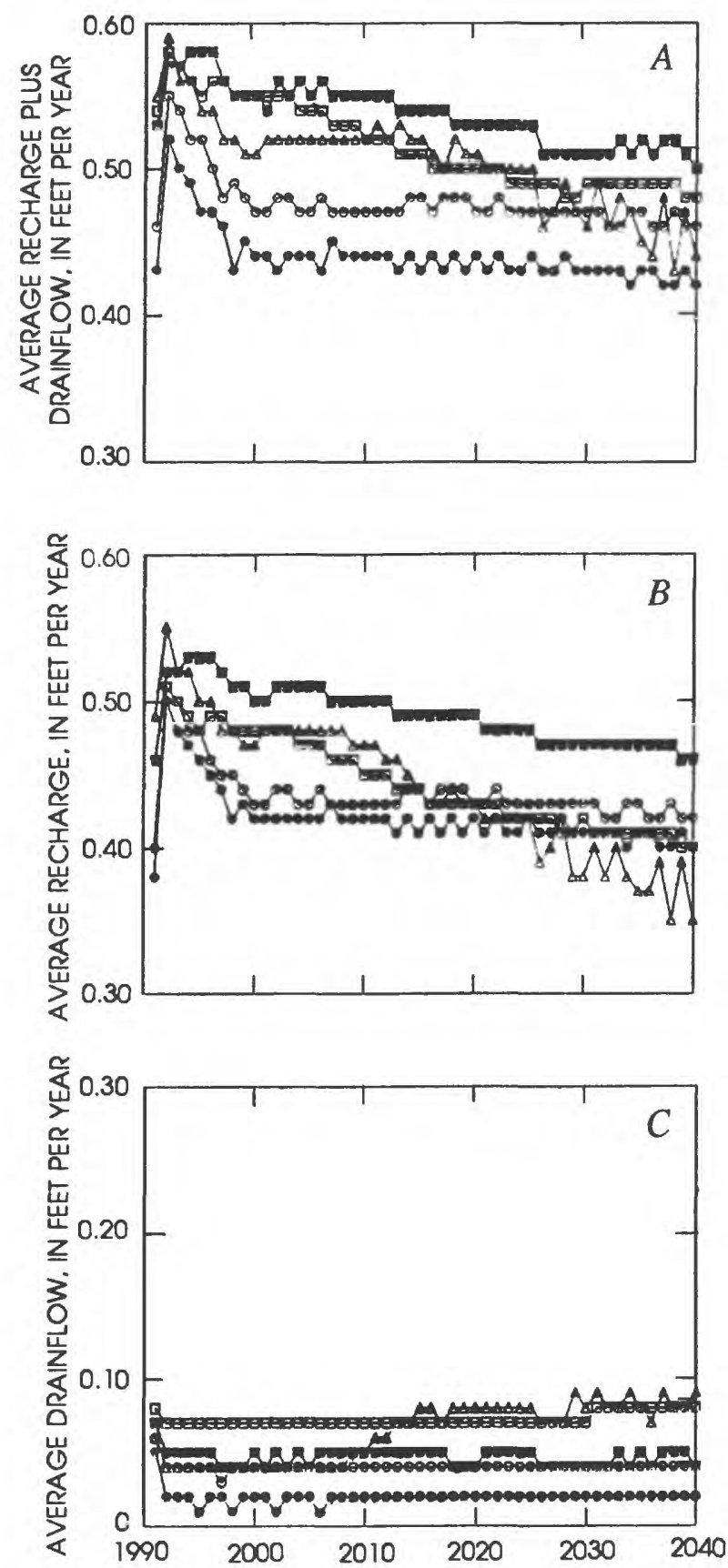

the WADE model because recharge rates were adjusted by drainflow as predicted by the WADE model.

Figure $27 A$ presents the regionally averaged recharge rates for the San Luis Unit as predicted by the WADE model, and figure $27 B$ presents the regionally averaged recharge rates after adjustment for drainflow (fig. $27 C$ ). Figure $27 D$ presents the regionally averaged
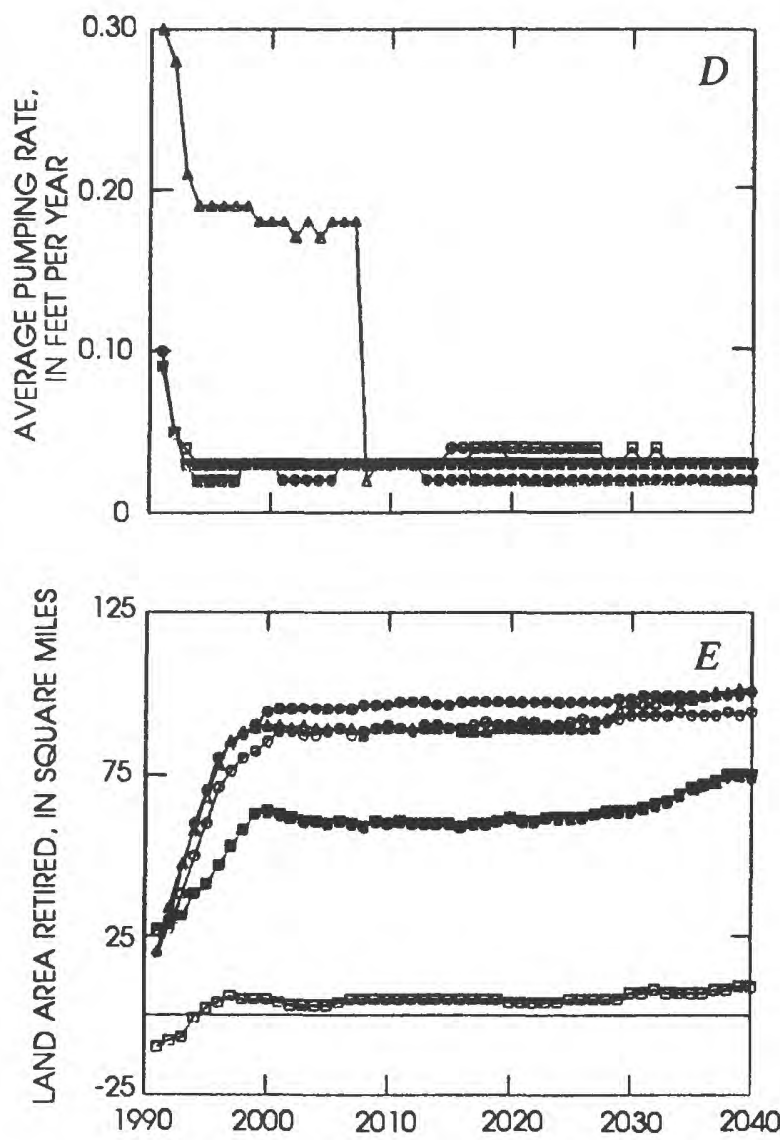

\section{EXPLANATION}

MANAGEMENT ALTERNATIVES
No action
1
2
3
4

Figure 27. Data provided by the U.S. Bureau of Reclamation for five management alternatives for the San Luis Unit. (See text p. 32 for explanation of management alternatives.) 
ground-water pumping rates for the San Luis Unit, and figure $27 E$ illustrates the amount of land in the San Luis Unit taken out of production. Aside from recharge, pumping, and the representation of drains, all other aspects of the model remained the same as the calibrated model. For model cells outside the San Luis Unit, all aspects of the model (including recharge, pumping, and drains) remained identical to the calibrated model.
Figure 28 presents a time-series plot of the number of cells subject to bare-soil evaporation that would result from the five management alternatives proposed by the USBR. Table 4 presents representative water budgets for 1991, 2007, 2025, and 2040 for that part of the San Luis Unit incorporated in the USGS model. The results illustrated in figure 28 and table 4 can be used as an additional tool for evaluating the USBR proposals.

Table 4. Water-budget data for 1991, 2007, 2025, and 2040 for that part of the San Luis Unit incorporated in the U.S. Geological Survey model

[Management alternatives: See text p. 32 for explanation of management alternatives. Confined horizontal flow: Positive values indicate net flow into the San Luis Unit; negative (-) values indicate net flow out of the unit. <, actual value is less than value shown. Values are in thousands of acre-feet]

\begin{tabular}{|c|c|c|c|c|c|}
\hline \multirow[b]{2}{*}{ Year } & \multicolumn{5}{|c|}{ Management alternative } \\
\hline & $\begin{array}{l}\text { No } \\
\text { action }\end{array}$ & 1 & 2 & 3 & 4 \\
\hline \multicolumn{6}{|c|}{ Recharge $^{1}$} \\
\hline 1991 & 120 & 120 & 105 & 105 & 135 \\
\hline 2007 & 140 & 125 & 120 & 120 & 130 \\
\hline 2025 & 135 & 115 & 115 & 120 & 115 \\
\hline 2040 & 130 & 110 & 115 & 115 & 100 \\
\hline \multicolumn{6}{|c|}{ Semiconfined Zone Storage } \\
\hline 1991 & 25 & 25 & 10 & 10 & 20 \\
\hline 2007 & 60 & 50 & 55 & 55 & 45 \\
\hline 2025 & 40 & 35 & 45 & 45 & 40 \\
\hline 2040 & 30 & 30 & 30 & 30 & 25 \\
\hline \multicolumn{6}{|c|}{ Semiconfined Zone Wells ${ }^{2}$} \\
\hline 1991 & 5 & 5 & 5 & 5 & 15 \\
\hline 2007 & $<5$ & $<5$ & $<5$ & $<5$ & 10 \\
\hline 2025 & $<5$ & $<5$ & $<5$ & $<5$ & $<5$ \\
\hline 2040 & $<5$ & $<5$ & $<5$ & $<5$ & $<5$ \\
\hline \multicolumn{6}{|c|}{ Semiconfined Zone Horizontal Flow } \\
\hline 1991 & 15 & 15 & 15 & 15 & 10 \\
\hline 2007 & 25 & 25 & 25 & 25 & 15 \\
\hline 2025 & 30 & 30 & 30 & 30 & 30 \\
\hline 2040 & 30 & 30 & 30 & 30 & 30 \\
\hline \multicolumn{6}{|c|}{ Evapotranspiration } \\
\hline 1991 & 15 & 15 & 15 & 15 & 15 \\
\hline 2007 & 30 & 20 & 15 & 15 & 15 \\
\hline 2025 & 40 & 25 & 25 & 25 & 25 \\
\hline 2040 & 45 & 30 & 30 & 35 & 25 \\
\hline
\end{tabular}

\begin{tabular}{|c|c|c|c|c|c|}
\hline \multirow[b]{2}{*}{ Year } & \multicolumn{5}{|c|}{ Management alternative } \\
\hline & $\begin{array}{l}\text { No } \\
\text { action }\end{array}$ & 1 & 2 & 3 & 4 \\
\hline \multicolumn{6}{|c|}{ Downward Vertical Flow } \\
\hline 1991 & 60 & 60 & 60 & 60 & 75 \\
\hline 2007 & 25 & 25 & 25 & 25 & 40 \\
\hline 2025 & 25 & 25 & 20 & 20 & 20 \\
\hline 2040 & 25 & 25 & 20 & 25 & 20 \\
\hline \multicolumn{6}{|c|}{ Confined Zone Storage } \\
\hline 1991 & 35 & 35 & 35 & 30 & 20 \\
\hline 2007 & 5 & 5 & 5 & 5 & 5 \\
\hline 2025 & $<5$ & $<5$ & $<5$ & $<5$ & $<5$ \\
\hline 2040 & $<5$ & $<5$ & $<5$ & $<5$ & $<5$ \\
\hline \multicolumn{6}{|c|}{ Confined Zone Wells ${ }^{2}$} \\
\hline 1991 & 20 & 20 & 25 & 25 & 65 \\
\hline 2007 & 10 & 10 & 10 & 10 & 35 \\
\hline 2025 & 5 & 10 & 5 & 10 & 5 \\
\hline 2040 & 5 & 10 & 5 & 10 & 5 \\
\hline \multicolumn{6}{|c|}{ Confined Zone Horizontal Flow } \\
\hline 1991 & 15 & 15 & 15 & 15 & 25 \\
\hline 2007 & -10 & -10 & -10 & -10 & 5 \\
\hline 2025 & -15 & -15 & -15 & -15 & -15 \\
\hline 2040 & -20 & -20 & -20 & -20 & -20 \\
\hline
\end{tabular}

${ }^{1}$ Recharge is regionally averaged recharge minus regionally averaged drainflow as projected by the WADE model.

${ }^{2}$ Semiconfined and confined zone well volumes are regionally averaged pumping volumes as projected by the WADE model. 


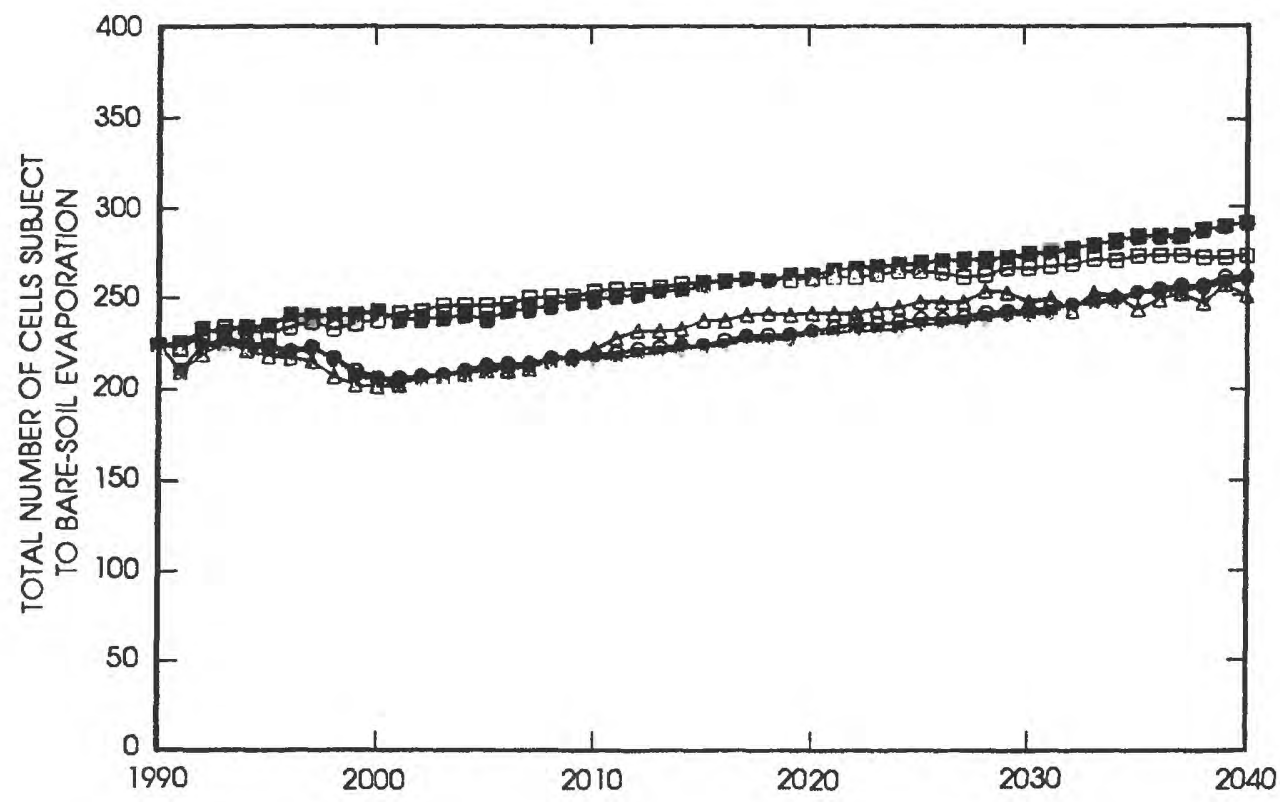

\section{EXPLANATION}

$\begin{array}{ll} & \text { MANAGEMENT ALTERNATIVES } \\ \text { - } & \text { No action } \\ \text { - } & 1 \\ \text { - } & 2 \\ - & 3 \\ \Delta & 4\end{array}$

Figure 28. Simulated effects on the number of model cells subject to baresoil evaporation for the five management alternatives proposed by the U.S. Bureau of Reclamation. (See text p. 32 for explanation of management alternatives.)

\section{DISCUSSION OF MANAGEMENT}

\section{ALTERNATIVES}

For each management alternative discussed in the previous section, the response of the water table was quantified in terms of the number of model cells subject to bare-soil evaporation and by drainflow in the area of on-farm drains. Each model cell represents $1 \mathrm{mi}^{2}$, and on-farm drains are present in 67 model cells. Table 5 summarizes the effects of the various management alternatives by 2040 .

Maintenance of present practices was defined as continuation of the areally distributed, but temporally constant rates of recharge and pumping that were specified in the calibration of the model. The model indicates that if recharge and pumping rates are maintained, the amount of land subject to bare-soil evaporation will increase from $224 \mathrm{mi}^{2}$ in 1990 to $344 \mathrm{mi}^{2}$ in 2040 , an increase of almost 50 percent; drainflow in the area of on-farm drains will increase from 0.55 to $0.65 \mathrm{ft} / \mathrm{yr}$, an increase of nearly 20 percent.

Retirement of land was defined as cessation of recharge and pumping. The model indicates that land retirement results in elimination of bare-soil evaporation in all cells retired, but has little effect on bare-soil evaporation in neighboring cells. The model also indicates that retirement results in elimination of drainflow in all cells retired and has a modest effect in adjacent areas. For example, the model indicates that if all cells subject to bare-soil evaporation in 
Table 5. Summary of the simulated effects of management alternatives by 2040

[Drainflow: Asterisk $\left(^{*}\right)$ indicates that drains were not modeled explicitly for these alternatives. Management units 1 to 4 are illustrated in figure 10. In 1990, the initial condition, the number of cells subject to bare-soil evaporation was 224 and the drainflow was $0.58 \mathrm{ft} / \mathrm{yr}$ ]

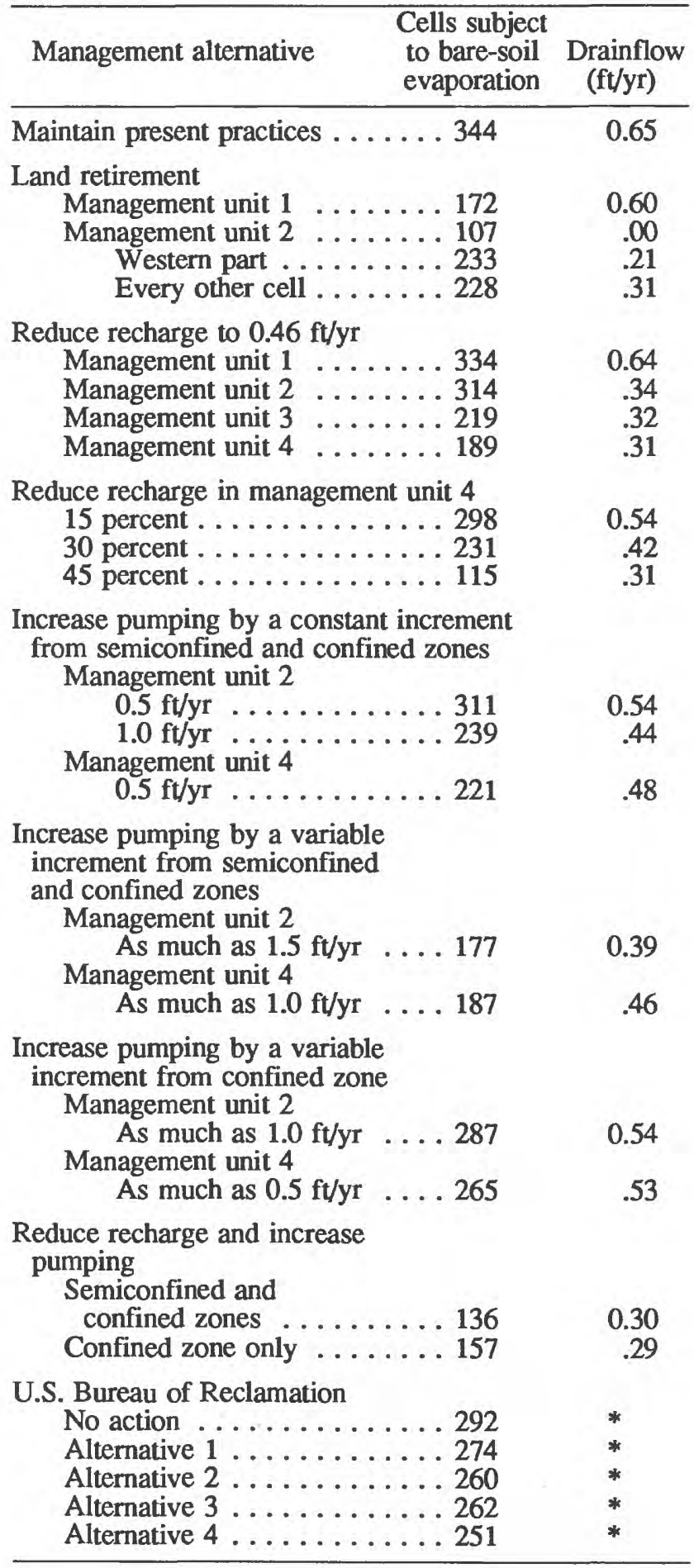

1990 are retired exclusive of the area underlain by on-farm drains, the drainflow in the area of on-farm drains will be reduced by 10 percent.

Two approaches were used to evaluate the sensitivity of the water table to a reduction in recharge. In the first approach, the size of the area in which recharge was reduced to $0.46 \mathrm{ft} / \mathrm{yr}$, a rate corresponding to the lowest recharge rate in the model area, was increased systematically. In the second approach, the 1980 recharge values were reduced systematically by a fixed percentage $(15,30,45$ percent $)$ in all model cells where the water table is above the Corcoran Clay Member (management unit 4). The model indicates that a reduction in recharge in areas not currently (1990) subject to bare-soil evaporation will be needed to control the occurrence of bare-soil evaporation in those areas. If recharge is reduced by 30 percent in management unit 4 , the total number of cells subject to bare-soil evaporation can be held to within 5 percent of the 1990 total. The model also indicates that drainflow is sensitive to the recharge rate in cells underlain by on-farm drains. A 30percent reduction in recharge in cells underlain by on-farm drains corresponds to a reduction in recharge of about $0.25 \mathrm{ft} / \mathrm{yr}$ and would result in a decrease in drainflow, relative to maintaining present practices, of about $0.22 \mathrm{ft} / \mathrm{yr}$.

An increase in ground-water pumping (relative to the calculated 1980 values) is an effective strategy for controlling the amount of area subject to bare-soil evaporation and for reducing drainflow. The effects of increased pumping were evaluated for three scenarios in two areas (management unit 4 and the area subject to bare-soil evaporation in 1990): (1) a constant increment in pumping from the semiconfined and confined zones; (2) a variable increment in pumping from the semiconfined and confined zones; and (3) a variable increment in pumping from the confined zone only. For each scenario, the increase in pumping was in increments of $0.5 \mathrm{ft} / \mathrm{yr}$, and the maximum pumping rate was defined as that pumping rate which would not cause a lowering of confined zone heads below the measured 1967 values; heads lower than 1967 values might result in land subsidence. 
The model indicates that if an additional 0.5 $\mathrm{ft} / \mathrm{yr}$ is pumped from the semiconfined and confined zones in management unit 4, or if an additional 1.0 $\mathrm{ft} / \mathrm{yr}$ is pumped from the areas currently (1990) subject to bare-soil evaporation, the amount of baresoil evaporation can be held relatively constant during the period of simulation, and drainflow can be reduced by about 30 percent, relative to maintaining present practices. If a variable increment in pumping is implemented from the semiconfined and confined zones, the model indicates a reduction in the number of cells subject to bare-soil evaporation, and a reduction in drainflow below the 1990 levels. If a variable increment in pumping is implemented from the confined zone only, the total number of cells subject to bare-soil evaporation, and the drainflow rate, will be about half-way between maintaining present practices and uniformly increasing pumping from the semiconfined and confined zones. The model does not simulate the transport of solutes in the system; therefore, the changes in the distribution of solutes that might occur as a consequence of increased ground-water pumping have not been evaluated.

A reduction in recharge combined with an increase in ground-water pumping is an effective strategy for controlling the altitude of the water table. The degree to which recharge can be reduced in any given subarea is partly a function of the availability of surface water. In three of the nine water-budget subareas, surface-water delivery exceeded calculated irrigation requirement. A reduction of recharge in these areas by an amount equal to the difference between surface-water delivery and calculated irrigation requirement would correspond to an overall decrease in recharge of 39 percent (about $0.3 \mathrm{ft} / \mathrm{yr}$ ). In five of the nine subareas, ground-water pumping supplements surface-water delivery. In these areas, the effects of reducing recharge by 15 percent (average reduction of about $0.1 \mathrm{ft} / \mathrm{yr}$ ) and increasing ground-water pumping by $0.5 \mathrm{ft} / \mathrm{yr}$ were evaluated. In one subarea, there is no surface-water delivery. In this area, any reduction in recharge would be offset by an equal reduction in ground-water pumping, and therefore no change in the water budget was implemented. If recharge is reduced and ground-water pumping is increased as described, the number of cells subject to bare-soil evaporation will be reduced by more than 40 percent, relative to 1990 conditions, and drainflow will be reduced by nearly 50 percent, relative to 1990 conditions. An increase in pumping from the confined zone is nearly as effective as pumping from the semiconfined and confined zones when coupled with a reduction in recharge. It is important to note that the reduction in recharge and increase in pumping were calculated relative to the 1980 water budget.

The U.S. Bureau of Reclamation (USBR) has evaluated five alternatives for the San Luis Unit, which is represented in this study area by $405 \mathrm{mi}^{2}$. The USBR evaluated the effects of the proposed management alternatives with a simulation model that is driven by on-farm economic decisions. The model discussed earlier in this report was used as an additional tool to evaluate the response of the water table. This model indicates that the most effective alternative evaluated by the USBR (alternative 4), from the perspective of the number of cells subject to bare-soil evaporation, would have a similar effect as uniformly increasing pumping by $1.0 \mathrm{ft} / \mathrm{yr}$ in management unit 2 or by reducing recharge by 30 percent in management unit 4 . In four of the five alternatives, 75 to $100 \mathrm{mi}^{2}$ of land in the study area would be taken out of irrigation. 


\section{SUMMARY AND CONCLUSIONS}

A transient, three-dimensional, numerical model was developed to simulate the ground-water flow system in the central part of the western San Joaquin Valley, California, with an emphasis on simulating the response of the water table to various management alternatives. The modeled area is $551 \mathrm{mi}^{2}$ and includes the semiconfined and confined zones above and below the Corcoran Clay Member of the Tulare Formation. The calibrated model incorporates areally distributed, but temporally constant recharge and pumping. The recharge and pumping rates were based on an analysis of 1980 water-budget data. The model also incorporates regional-collector drains in the Westlands Water District (operative from 1981 to 1985), on-farm drains in parts of the Firebaugh, Panoche, and Broadview Water Districts, and bare-soil evaporation from the water table (which occurs if the water table is within 7 $\mathrm{ft}$ of land surface). The model, which was calibrated using hydrologic data from 1972 to 1988, simulated the average change in the altitude of the water table to within 4 percent.

The calibrated model was used to evaluate the response of the water table to various management alternatives. For the purposes of analysis, 1990 was selected as the year in which the different alternatives would become operational. The management alternatives evaluated were maintenance of present practices, land retirement, reduced recharge, increased groundwater pumping, combinations of these alternatives, and five alternatives proposed by the U.S. Bureau of Reclamation. In each alternative, the response of the water table was quantified in terms of the number of model cells subject to bare-soil evaporation and by drainflow in the area of on-farm drains.

Maintenance of present practices was defined as continuation of the areally distributed, but temporally constant rates of recharge and pumping that were specified in the calibration of the model. The model indicates that if recharge and pumping rates are maintained, the amount of land subject to bare-soil evaporation will increase by about 50 percent and drainflow in the area of on-farm drains will increase by about 20 percent.

Retirement of land was defined as the cessation of recharge and pumping in areas removed from agricultural production. The model indicates that land retirement results in elimination of bare-soil evaporation and reduction in drainflow in all cells retired, but has little effect on neighboring cells.
Recharge can be reduced through improvements in irrigation practices and technology that are designed to maximize irrigation efficiency. The simulated effects of reducing recharge varied with the magnitude of reduction and the size of the area managed. The model indicates that bare-soil evaporation can be held virtually constant if recharge is reduced by 30 percent in management unit 4 where the water table is above the Corcoran Clay Member. Reduction of recharge in areas not currently subject to bare-soil evaporation appears to be an effective means for controlling the occurrence of bare-soil evaporation in those areas.

Increasing ground-water pumping over average values can reduce bare-soil evaporation and drainflow substantially. If variable pumping increments are used in the semiconfined and confined zones, the model indicates a reduction in bare-soil evaporation and drainflow below 1990 levels. Smaller reductions in bare-soil evaporation and drainflow were simulated when increased pumping was restricted to the confined zone only. Care was taken to avoid drawdowns in the confined zone that could cause subsidence. The model does not simulate the transport of solutes in the system; therefore, the changes in the distribution of solutes that might occur as a consequence of increased groundwater pumping have not been evaluated.

A combination of reducing recharge and increasing ground-water pumping is an effective strategy for reducing bare-soil evaporation and drainflow. The model indicates that the combined effect of these management alternatives results in a 40-percent reduction in bare-soil evaporation, and a 50-percent reduction in drainflow relative to 1990 conditions.

Analysis of five management alternatives proposed by the U.S. Bureau of Reclamation (USBR) indicates that the most effective USBR alternative has an effect similar to reducing recharge by 30 percent in management unit 4 where the water table is above the Corcoran Clay Member. The USBR alternatives are not directly comparable to other alternatives presented, as the USBR study area is about 25 percent smaller than the model area.

In conclusion, the model indicates that the amount of land subject to bare-soil evaporation and the amount of drainflow in the model area can be reduced from the current (1990) levels by more than 40 and 50 percent, respectively, if recharge is reduced by 15 percent (about $0.1 \mathrm{ft} / \mathrm{yr}$ ) and pumping is increased by $0.5 \mathrm{ft} / \mathrm{yr}$ in areas that currently use surface water and ground water, and if recharge is reduced by about 40 percent (about $0.3 \mathrm{ft} / \mathrm{yr}$ ) in areas that currently use surface water only. 


\section{REFERENCES CITED}

Belitz, Kenneth, and Heimes, F.J., 1990, Character and evolution of the ground-water flow system in the central part of the western San Joaquin Valley, California: U.S. Geological Survey Water-Supply Paper 2348, 28 p.

Belitz, Kenneth, Phillips, S.P., and Gronberg, J.M., 1992, Numerical simulation of ground-water flow in the central part of the western San Joaquin Valley, California: U.S. Geological Survey Open-File Report 91-535.

Davis, G.H., and Poland, J.F., 1957, Ground-water conditons in the Mendota-Huron area, Fresno and Kings Counties, California: U.S. Geological Survey WaterSupply Paper 1360-G, p. 409-588.

Deverel, S.J., Gilliom, R.J., Fujii, Roger, Izbicki, J.A., and Fields, J.C., 1984, Areal distribution of selenium and other inorganic constituents in shallow ground water of the San Luis Drain service area, San Joaquin Valley, California--A preliminary study: U.S. Geological Survey Water-Resources Investigation Report 84-4319, 67 p.

Gronberg, J.M., and Belitz, Kenneth, 1992, Estimation of a water budget for the central part of the westem San Joaquin Valley, California: U.S. Geological Survey Water-Resources Investigation Report 91-4192.

Hatchett, S.A., Horner, G.L., and Howitt, R.E., 1991, A regional mathematical programming model to assess drainage control policies, in Dinar, Ariel, and Zilberman, David, eds., The Economics and Management of Water and Drainage in Agriculture: Boston, Massachusetts, Kluwer Academic Publishers.

Laudon, Julie, and Belitz, Kenneth, 1991, Texture and depositional history of Late Pleistocene-Holocene alluvium in the central part of the western San Joaquin Valley, California: Bulletin of the Association of Engineering Geologists, v. 28, no. 1, p. 73-88.
Miller, R.E., Green, J.H., and Davis, G.H., 1971, Geology of the compacting deposits in the Los Banos-Kettleman City subsidence area, California: U.S. Geological Survey Professional Paper 497-E, 46 p.

Ohlendorf, H.M., Hothem, R.L., Bunck, C.M., Aldrich, T.W., and Moore, J.F., 1986, Relationships between selenium concentrations and avian reproduction: North American Wildlife and Natural Resources Conference, 51st, Reno, Nevada, p. 330-442.

Phillips, S.P., and Belitz, Kenneth, 1991, Calibration of a texture-based model of a ground-water flow system, western San Joaquin Valley, California: Ground Water, v. 29 , no. 5 , p. $702-715$.

Presser, T.S., and Barnes, Ivan, 1985, Dissolved constituents including selenium in waters in the vicinity of Kesterson National Wildlife Refuge and the West Grassland, Fresno and Merced Counties, California: U.S. Geological Survey Water-Resources Investigations Report 84-4220, 73 p.

San Joaquin Valley Drainage Program, 1989a, Preliminary planning alternatives for solving agricultural drainage and drainage-related problems in the San Joaquin Valley: $337 \mathrm{p}$.

$1989 \mathrm{~b}$, Overview of the use of the Westside Agricultural Drainage Economics Model (WADE) for plan evaluation, 68 p., 8 tables, 52 figs., 4 appendixes.

U.S. Bureau of Reclamation, 1991, Draft environmental impact statement, San Luis Unit Drainage Program, Central Valley Project, California: U.S. Bureau of Reclamation, DES 91-36, 270 p.

Williamson, A.K., Prudic, D.E., and Swain, L.A., 1989, Ground-water flow in the Central Valley, California: U.S. Geological Survey Professional Paper 1401-D, $127 \mathrm{p}$. 
Table 6. Changes in model cells subject to bare-soil evaporation and in drainflow for all management alternatives

[Drainflow is not shown for the five alternatives proposed by the U.S. Bureau of Reclamation because drains were not explicitly modeled for these alternatives]

\begin{tabular}{ccc}
\hline Year & $\begin{array}{c}\text { Growth Eliminated } \\
\text { (number of model cells) }\end{array}$ & $\begin{array}{c}\text { Trainflow } \\
\text { (ft/yr) }\end{array}$ \\
\hline
\end{tabular}

Maintain present practices

$\begin{array}{rrrrr}2000 & 55 & 0 & 279 & 0.61 \\ 2010 & 85 & 0 & 309 & .62 \\ 2020 & 98 & 0 & 322 & .64 \\ 2030 & 109 & 0 & 333 & .64 \\ 2040 & 120 & 0 & 344 & .65\end{array}$

Retire management unit 1

$\begin{array}{rrrrr}2000 & 52 & 160 & 116 & 0.58 \\ 2010 & 73 & 161 & 136 & .59 \\ 2020 & 84 & 161 & 147 & .59 \\ 2030 & 98 & 161 & 161 & .60 \\ 2040 & 109 & 161 & 172 & .60\end{array}$

Retire management unit 2

$\begin{array}{rrrrr}2000 & 52 & 224 & 52 & 0.00 \\ 2010 & 73 & 224 & 73 & .00 \\ 2020 & 83 & 224 & 83 & .00 \\ 2030 & 95 & 224 & 95 & .00 \\ 2040 & 107 & 224 & 107 & .00\end{array}$

Retire western part of management unit 2

$\begin{array}{lrlll}2000 & 59 & 112 & 171 & 0.21 \\ 2010 & 86 & 112 & 198 & .21 \\ 2020 & 99 & 113 & 210 & .21 \\ 2030 & 110 & 113 & 221 & .21 \\ 2040 & 122 & 113 & 233 & .21\end{array}$

Retire every other cell in management unit 2

$\begin{array}{rrrrr}2000 & 42 & 112 & 154 & 0.29 \\ 2010 & 76 & 113 & 187 & .30 \\ 2020 & 88 & 113 & 199 & .30 \\ 2030 & 108 & 113 & 219 & .30 \\ 2040 & 117 & 113 & 228 & .31\end{array}$

Reduce recharge to $0.46 \mathrm{ft} / \mathrm{yr}$ in management unit 1

$\begin{array}{rrrrr}2000 & 39 & 13 & 250 & 0.60 \\ 2010 & 75 & 9 & 290 & .62 \\ 2020 & 91 & 8 & 307 & .63 \\ 2030 & 108 & 7 & 325 & .64 \\ 2040 & 117 & 7 & 334 & .64\end{array}$

Reduce recharge to $0.46 \mathrm{ft} / \mathrm{yr}$ in management unit 2

$\begin{array}{rrrrr}2000 & 39 & 41 & 222 & 0.30 \\ 2010 & 75 & 33 & 266 & .32 \\ 2020 & 91 & 29 & 286 & .33 \\ 2030 & 108 & 28 & 304 & .33 \\ 2040 & 117 & 27 & 314 & .34\end{array}$

\begin{tabular}{ccc}
\hline Year & $\begin{array}{c}\text { Growth Eliminated Total } \\
\text { (number of model cells) }\end{array}$ & $\begin{array}{c}\text { Drainflow } \\
\text { (ft/yr) }\end{array}$ \\
\hline
\end{tabular}

Reduce recharge to $0.46 \mathrm{ft} / \mathrm{yr}$ in management unit 3

$\begin{array}{lllll}2000 & 11 & 59 & 176 & 0.28 \\ 2010 & 15 & 52 & 187 & .30 \\ 2020 & 22 & 47 & 199 & .31 \\ 2030 & 30 & 45 & 209 & .32 \\ 2040 & 37 & 42 & 219 & .32\end{array}$

Reduce recharge to $0.46 \mathrm{ft} / \mathrm{yr}$ in management unit 4

$\begin{array}{lllll}2000 & 10 & 62 & 172 & 0.28 \\ 2010 & 15 & 59 & 180 & .29 \\ 2020 & 15 & 56 & 183 & .30 \\ 2030 & 16 & 54 & 186 & .30 \\ 2040 & 19 & 54 & 189 & .31\end{array}$

Reduce recharge by 15 percent in management unit 4

$\begin{array}{lllll}2000 & 23 & 6 & 241 & 0.51 \\ 2010 & 37 & 2 & 259 & .52 \\ 2020 & 53 & 2 & 275 & .53 \\ 2030 & 68 & 2 & 290 & .54 \\ 2040 & 76 & 2 & 298 & .54\end{array}$

Reduce recharge by 30 percent in management unit 4

$\begin{array}{lclll}2000 & 6 & 30 & 200 & 0.39 \\ 2010 & 14 & 29 & 209 & .41 \\ 2020 & 21 & 29 & 216 & .42 \\ 2030 & 26 & 26 & 224 & .42 \\ 2040 & 32 & 25 & 231 & .42\end{array}$

Reduce recharge by 45 percent in management unit 4

$\begin{array}{lclll}2000 & 1 & 110 & 115 & 0.28 \\ 2010 & 2 & 113 & 113 & .29 \\ 2020 & 5 & 117 & 112 & .30 \\ 2030 & 7 & 118 & 113 & .30 \\ 2040 & 10 & 119 & 115 & .31\end{array}$

Increase pumping by $0.5 \mathrm{ft} / \mathrm{yr}$ from semiconfined and confined zones in management unit 2

$\begin{array}{lllll}2000 & 27 & 8 & 243 & 0.53 \\ 2010 & 54 & 8 & 270 & .53 \\ 2020 & 68 & 8 & 284 & .54 \\ 2030 & 81 & 8 & 297 & .54 \\ 2040 & 95 & 8 & 311 & .54\end{array}$

Increase pumping by $1.0 \mathrm{ft} / \mathrm{yr}$ from semiconfined and confined zones in management unit 2

$\begin{array}{lllll}2000 & 20 & 40 & 204 & 0.42 \\ 2010 & 32 & 47 & 209 & .43 \\ 2020 & 44 & 49 & 219 & .43 \\ 2030 & 53 & 48 & 229 & .44 \\ 2040 & 63 & 48 & 239 & .44\end{array}$


Table 6. Changes in model cells subject to bare-soil evaporation and in drainflow for all management alternatives--Continued

\begin{tabular}{ccc}
\hline Year & $\begin{array}{c}\text { Growth Eliminated Total } \\
\text { (number of model cells) }\end{array}$ & $\begin{array}{c}\text { Drainflow } \\
\text { (ft/yr) }\end{array}$ \\
\hline
\end{tabular}

Increase pumping by $0.5 \mathrm{ft} / \mathrm{yr}$ from semiconfined and confined zones in management unit 4

$\begin{array}{llllr}2000 & 19 & 30 & 213 & 0.48 \\ 2010 & 28 & 42 & 210 & .48 \\ 2020 & 37 & 47 & 214 & .48 \\ 2030 & 43 & 49 & 218 & .48 \\ 2040 & 47 & 50 & 221 & .48\end{array}$

Increase pumping by a variable increment from semiconfined and confined zones in management unit 2 (maximum increment of $1.5 \mathrm{ft} / \mathrm{yr}$ )

$\begin{array}{lllll}2000 & 16 & 80 & 160 & 0.39 \\ 2010 & 23 & 84 & 163 & .39 \\ 2020 & 31 & 85 & 170 & .39 \\ 2030 & 38 & 90 & 172 & .39 \\ 2040 & 45 & 92 & 177 & .39\end{array}$

Increase pumping by variable increment from semiconfined and confined zones in management unit 4 (maximum increment of $1.0 \mathrm{ft} / \mathrm{yr}$ )

$\begin{array}{llllr}2000 & 17 & 45 & 196 & 0.49 \\ 2010 & 26 & 55 & 195 & .48 \\ 2020 & 28 & 60 & 192 & .47 \\ 2030 & 29 & 66 & 187 & .47 \\ 2040 & 30 & 67 & 187 & .46\end{array}$

Increase pumping by a variable increment from the confined zone only in management unit 2 (maximum increment of $1.0 \mathrm{ft} / \mathrm{yr}$ )

$\begin{array}{llllr}2000 & 27 & 4 & 247 & 0.53 \\ 2010 & 42 & 7 & 259 & .53 \\ 2020 & 57 & 7 & 274 & .53 \\ 2030 & 62 & 7 & 279 & .54 \\ 2040 & 70 & 7 & 287 & .54\end{array}$

Increase pumping by a variable increment from the confined zone in management unit 4 (maximum increment of $0.5 \mathrm{ft} / \mathrm{yr}$ )

$\begin{array}{rrrrr}2000 & 26 & 7 & 243 & 0.54 \\ 2010 & 36 & 8 & 252 & .54 \\ 2020 & 47 & 10 & 261 & .53 \\ 2030 & 53 & 13 & 264 & .53 \\ 2040 & 55 & 14 & 265 & .53\end{array}$

Reduce recharge and increase pumping from semiconfined and confined zones

$\begin{array}{lrrrr}2000 & 4 & 94 & 134 & 0.29 \\ 2010 & 12 & 102 & 134 & .29 \\ 2020 & 18 & 105 & 137 & .29 \\ 2030 & 21 & 111 & 134 & .29 \\ 2040 & 23 & 111 & 136 & .30\end{array}$

\begin{tabular}{ccc}
\hline Year & $\begin{array}{c}\text { Growth Eliminated } \\
\text { (number of model cells) }\end{array}$ & $\begin{array}{c}\text { Total } \\
\text { Drainflow } \\
(\mathrm{ft} / \mathrm{yr})\end{array}$ \\
\hline
\end{tabular}

Reduce recharge and increase pumping from confined zone only

\begin{tabular}{lrrrr}
2000 & 8 & 60 & 172 & 0.29 \\
2010 & 15 & 72 & 167 & .29 \\
2020 & 19 & 80 & 163 & .29 \\
2030 & 24 & 84 & 164 & .29 \\
2040 & 24 & 91 & 157 & .29 \\
\hline Year & Growth & $\begin{array}{c}\text { Eliminated } \\
\text { (number of model cells) }\end{array}$ & Total \\
\hline
\end{tabular}

Management of San Luis Unit by U.S. Bureau of Reclamation - "No action"

$\begin{array}{lrll}2000 & 49 & 30 & 243 \\ 2010 & 68 & 43 & 249 \\ 2020 & 81 & 42 & 263 \\ 2030 & 93 & 42 & 275 \\ 2040 & 109 & 41 & 292\end{array}$

Management of San Luis Unit by U.S. Bureau of Reclamation - Alternative 1

$\begin{array}{llll}2000 & 40 & 26 & 238 \\ 2010 & 55 & 25 & 254 \\ 2020 & 60 & 23 & 261 \\ 2030 & 68 & 25 & 267 \\ 2040 & 75 & 25 & 274\end{array}$

Management of San Luis Unit by U.S. Bureau of Reclamation - Alternative 2

$\begin{array}{llll}2000 & 31 & 50 & 205 \\ 2010 & 47 & 54 & 217 \\ 2020 & 58 & 52 & 230 \\ 2030 & 67 & 50 & 241 \\ 2040 & 84 & 44 & 260\end{array}$

Management of San Luis Unit by U.S. Bureau of Reclamation - Alternative 3

$\begin{array}{llll}2000 & 32 & 50 & 206 \\ 2010 & 47 & 52 & 219 \\ 2020 & 58 & 50 & 232 \\ 2030 & 67 & 45 & 243 \\ 2040 & 85 & 43 & 262\end{array}$

Management of San Luis Unit by U.S. Bureau of Reclamation - Alternative 4

\begin{tabular}{llll}
2000 & 29 & 52 & 201 \\
2010 & 45 & 47 & 222 \\
2020 & 58 & 40 & 242 \\
2030 & 68 & 44 & 248 \\
2040 & 80 & 53 & 251 \\
\hline
\end{tabular}

